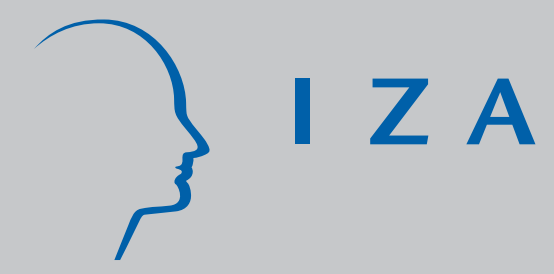

IZA DP No. 2058

Is Mothers' Time With Their Children Home Production or Leisure?

J ean Kimmel

Rachel Connelly

March 2006 


\title{
Is Mothers' Time With Their Children Home Production or Leisure?
}

\author{
Jean Kimmel \\ Western Michigan University \\ and IZA Bonn \\ Rachel Connelly \\ Bowdoin College
}

\section{Discussion Paper No. 2058 \\ March 2006}

\author{
IZA \\ P.O. Box 7240 \\ 53072 Bonn \\ Germany \\ Phone: +49-228-3894-0 \\ Fax: +49-228-3894-180 \\ Email: iza@iza.org
}

\begin{abstract}
Any opinions expressed here are those of the author(s) and not those of the institute. Research disseminated by IZA may include views on policy, but the institute itself takes no institutional policy positions.

The Institute for the Study of Labor (IZA) in Bonn is a local and virtual international research center and a place of communication between science, politics and business. IZA is an independent nonprofit company supported by Deutsche Post World Net. The center is associated with the University of Bonn and offers a stimulating research environment through its research networks, research support, and visitors and doctoral programs. IZA engages in (i) original and internationally competitive research in all fields of labor economics, (ii) development of policy concepts, and (iii) dissemination of research results and concepts to the interested public.
\end{abstract}

IZA Discussion Papers often represent preliminary work and are circulated to encourage discussion. Citation of such a paper should account for its provisional character. A revised version may be available directly from the author. 


\section{ABSTRACT \\ Is Mothers' Time With Their Children Home Production or Leisure?*}

As mothers have increased their paid work efforts, conflicts between employment and family responsibilities have grown. This evolution has led researchers to explore more fully the role that caregiving responsibilities play in mothers' time choices. We study this issue using data from the 2003 American Time Use Survey. We estimate a simultaneous four-equation system in which the dependent variables are the number of minutes in a mother's diary day that she devotes to home production, leisure, market work, and caregiving. The first goal of this estimation is to determine if time spent with children responds to prices and demographics more like home production time or leisure. The second goal is to glean a better understanding of the importance that marital status, race, and other demographic factors play in time choices, once economic factors are controlled. Our final goal is to improve upon the existing time use literature by estimating a structural time use model that produces explicit estimates of wage and child care price elasticities. Our results show that mothers' time with their children does not respond to price or demographic changes much like home production or leisure and that, somewhat surprisingly, the caregiving choice responds most like paid labor particularly in the response to higher wages.

JEL Classification: J13, J22

Keywords: child care, time allocation

Corresponding author:

Jean Kimmel

Department of Economics

Western Michigan University

Kalamazoo, MI 49008-5091

USA

Email: jean.kimmel@wmich.edu

\footnotetext{
* The authors thank the W.E. Upjohn Institute for Employment Research for the financial support they have provided for this research. We also thank Dawit Senbet for research assistance. Earlier drafts of this manuscript were presented at the November 2005 SEA meeting, December 2005 ATUS Early Results Conference sponsored by the BLS, and the January 2006 ASSA meeting.
} 


\section{Is Mothers’ Time With Their Children Home Production or Leisure?}

The twentieth century was a period of dramatic transformation in the role that women play in society, highlighted most clearly by the rapid rise in paid employment of mothers with young children. Currently, about 60 percent of mothers with children under age six participate in the paid workforce. As mothers have increased their paid work efforts, conflicts between employment and family responsibilities have grown, leading researchers to explore more fully the role that caregiving responsibilities play in mothers' time choices and the effects that these choices may be expected to have on their children.

Our paper relies on the recently-released American Time Use Survey (ATUS) data to describe the time use choices of mothers in the United States. Using these data, we describe how mothers divide their time among home production, caregiving time, leisure, and paid market work, with a focus on identifying differential responses to demographics and prices for the different time uses. The first goal of the paper is to determine if time spent with children is best categorized as household production or leisure time. This question arises because time spent with children differs conceptually from either home production, which is usually considered to have immediate payoffs, and leisure, which is usually considered completely discretionary. Thus, there is no a priori justification for considering child care time to be leisure or household production. By comparing the responsiveness of time spent in home production, child care, and leisure to various demographic and economic factors, we hope to determine how best to categorize time spent with children. Our conclusion is that child care time is a time use clearly distinct from household production as well as leisure. 
The second motivation for this research is to gain a better understanding of the importance that marital status, race, and other demographic factors play in time choices, once economic factors are controlled. We expect to find that single mothers make time use decisions very differently from their married counterparts, in part due to the lesser availability of adults in the household to engage in home production, resulting in a greater need to purchase products in the market. With regard to race, previous child care research has revealed different child care utilization patterns by race, and we expect these differences to carry over to time use as well. Difference in time use by race may help explain differences observed in other policy relevant variables such as differences by race in the gender wage gap or in wealth acquisition.

Finally, our third goal with this research is to fill the gap in the existing time use literature by estimating a structural time use model that produces explicit estimates of wage and child care price elasticities. With this methodological improvement, we can estimate the elasticity of time changes with respect to wages and child care prices. We find that time use of mothers in the United States is sensitive to wages and child care prices of preschoolers but less responsive to child care prices for school-age children. Employment time on weekdays responds as we would expect, with increased wages increasing employment time while increased child care prices reduce employment time. Note that this is employment time on a given day, not total employment time, so that differences could occur as employment may be fungible across days of the week. In fact, we find the employment time on weekends responds differently than weekday time with respect to the price of child care. On weekends, the elasticity of employment time is positive with respect to the price of child care even as it continues to be positive with respect to the wage rate. These results show that we must be careful when we think about time elasticities per day as opposed to weekly labor supply or annual labor supply. The rich time diary data 
allows us a much more micro look at time choices across the week, across mothers with different household structure, and across different economic characteristics.

The rest of the paper is as follows: Section II reviews the economic literature on time allocation from the Robbins labor/leisure tradeoff model through the work of Becker and Gronau, and concluding with the empirical literature that looks explicitly at child care time. Section III outlines a behavior model of four distinct time uses for mothers of young children, while Section IV discusses the ATUS data and our estimation strategy. Section V presents our results and Section VI summarizes the findings.

\section{II: Time Allocation Models and Mothers’ Time Use}

Economists have long understood that the standard Robbins (1930) labor/leisure model is inadequate for understanding the time allocation process of mothers. Many tasks of child raising such as changing diapers or encouraging one's child to do his homework bring little direct utility and are not classified appropriately as leisure. The New Home Economics (NHE) models of the early 1960's acknowledged that a substantial portion of time not spent in paid employment is home production time, not leisure. ${ }^{1}$ Becker’s (1965) methodology omits all time categorizations and focuses on the production of final consumption commodities, but this approach has been difficult to implement empirically due to the difficulty identifying the final commodities. Since then, alternative approaches have focused on expanding the traditional two-dimensional time allocation model to three or more uses of time. Gronau (1977) and Graham and Green (1984) aggregated time outside the labor market into home production and pure leisure. Gronau (1977) establishes two criteria for aggregating time uses and concludes that leisure time and home production time should not be combined. Gronau writes: "From the theoretical point of view,

\footnotetext{
${ }^{1}$ See, most importantly for our purpose here, Becker (1965), Gronau (1977), Graham and Green (1984).
} 
the justification of aggregating leisure and work at home into one entity, nonmarket time (or home time) can rest on two assumptions: (a) the two elements react similarly to changes in the socioeconomic environment and therefore nothing is gained by studying them separately, and (b) the two elements satisfy the condition of a composite input, that is, their relative price is constant and there is no interest in investigating the composition of the aggregate since it has no bearing on production and the price of the output.” (p. 1100)

Gronau's principles explain why, particularly for mothers, three uses of time are also not enough. In his model, "home work" is for the purpose of producing a good that one could also purchase in the market. Home produced goods and market produced goods are indistinguishable and the production process provides no utility per se. However, home-produced child care (henceforth referred to as parental child care) is often considered an imperfect substitute for market child care in the production of child services, and some of the time spent in parental child care provides positive utility to parents. For studying the time use of mothers, the best solution to this problem is to expand the Gronau trinity into a model with four aggregated uses of time: (paid) market work, (unpaid) home work, child care and leisure (see, for example, Van den Brink and Groot (1997)). ${ }^{2}$

Defining what one means by "child care" time or measuring that caregiving time is not always straightforward. Only a portion of mothers' time with their children can be thought of as babysitting in the traditional sense. This time would include feeding and bathing the kids, or playing games and reading with them. Presumably, these are the sorts of activities that the ATUS picks up in primary caregiving time, time when the respondent herself categorizes the

\footnotetext{
${ }^{2}$ Kooreman and Kapteyn (1987) use eight categories of time use, but that is more than necessary for a parsimonious model.
} 
time as primarily child care activities. Other activities in which children are involved are more likely categorized as time spent with children, such as the always pleasurable trip to the supermarket with squabbling children in tow. ${ }^{3}$ Finally, there is passive care that the ATUS collects as time when children are recorded as "in your care” which excludes time when all household children are sleeping and the time when the respondent is sleeping. Passive care includes time at home when one is listening for children calling or overseeing children engaged in play. Folbre et al (2005, pg. 374) encourage moving beyond the simple categorization of time into activities to incorporate even broader notions of responsibilities or constraints. Thus, their description of passive care would be broader than that available in the ATUS, and would include being responsible for sleeping children, even if the parents are sleeping too.

Unfortunately, the data produced by existing time use surveys do not reflect the broad characterization suggested by Folbre et al. Two recent papers by Kalenkoski, Ribar and Stratton (2005a, 2005b) address this measurement issue by focusing on different measures of nonprimary caregiving. In their first 2005 paper, Kalenkoski, Ribar and Stratton use data from the United Kingdom to examine factors important to primary and secondary child care (as well as market) time use, while their second paper (using data from both the U.K. and the United States), uses a broader definition of secondary care that includes all time spent with children not reported as the primary activity (pg. 10). ${ }^{4}$ For this paper we have limited our definition of child care time to primary activities but have included some activities beyond the category of "Caring and Helping Household Children” such as travel time related to caring for children, travel time related to using non-parental child care and time spent engaging non-parental child care.

\footnotetext{
${ }^{3}$ Kalenkoski et al (2005a) examine child care time both as primary and secondary time usages.

${ }^{4}$ ATUS permits respondents to record child care as a secondary activity when it is not the reported primary activity.
} 
What is the existing state of knowledge regarding mothers' time use patterns? The bulk of the previous literature that examines caregiving time focuses on couples, often dual earner households. Kooreman and Kapteyn (1987) looked exclusively at married couples and found that higher wages of the father increased the time their wives spent in child care but that women's own wages affected neither her child care time nor her husband's child care time. Nock and Kingston (1988) found that mother's employment reduced their child care time, but that the reductions were mostly in secondary activities with children. ${ }^{5}$ Using data from the Netherlands, for married mothers currrently employed, Van Den Brink and Groot (1997) found no affect of husband's earnings on time allocation of his wife in employment, home production or child care.

Studies using more recent time diary data from the U.S. found that employment hours are a predictor of hours spent with children; however, mothers appear to shield their children from the full impact of their employment by cutting back on personal time, sleep, leisure and home production rather than child care. Thus, there is some evidence that child care time is treated differently than either home production or leisure. ${ }^{6}$

More recently, Kalenkoski, Ribar and Stratton (2005a) use British data to estimate a reduced form model, so wages are not included directly. They find that women with an advanced degree spend more time on primary child care, secondary child care and market work. What they are spending less time on is not clear because their model ignores all other time uses. Kalenkoski, Ribar and Stratton (2005b) show a similar result for U.S. mothers, namely that mothers with a bachelor's degree or a graduate degree spend more time on primary child care

\footnotetext{
${ }^{5}$ Both papers use data from U.S time diaries from the 1975-1981 Time Use Longitudinal Panel.

${ }^{6}$ For examples of this research, see Howie, et al (2005), Bianchi (2000 and 2005), Reimers (2002), Sandberg and Hofferth (2001) and Bryant and Zick (1996).
} 
and in market employment. Closest to our research is that by Hallberg and Klevmarken (2003). They examine the determinants of parents' time allocated to childcare in Sweden and their structural model incorporates instruments for both parents' wages and parents' employment time. They find that own wages do not affect child care time of their sample of Swedish parents.

\section{III: Underlying Behavioral Model}

The behavioral model underlying our empirical specification is a typical individual-based utility maximizing problem in which mother's utility is expressed as a function of leisure, $t_{L}$, child services, CS, and aggregated adult consumption of final goods and services excluding child services, G.

$$
\max \mathrm{U}=\mathrm{U}\left(\mathrm{t}_{\mathrm{L}}, \mathrm{CS}, \mathrm{G}\right)
$$

Adult consumption goods, G, are home produced with a combination of household production time, $t_{h p}$, and purchased intermediate goods; $G=G\left(t_{h p}, X\right)$. Child services, CS, are also home produced but with a combination of the mother’s caregiving time, $\mathrm{t}_{\mathrm{mcc}}$, nonmaternal child care time (including that provided by the father), $\mathrm{t}_{\mathrm{cc}}$, and market-produced child goods, CX; $\mathrm{CS}=\mathrm{CS}\left(\mathrm{t}_{\mathrm{mcc}}, \mathrm{t}_{\mathrm{cc}}, \mathrm{CX}\right)$. On the constraint side of the model, there is a mother's time constraint, equation 2, and a budget constraint, equation 3.

$$
\begin{aligned}
& \mathrm{T}=\mathrm{t}_{\mathrm{em}}+\mathrm{t}_{\mathrm{hp}}+\mathrm{t}_{\mathrm{mcc}}+\mathrm{t}_{\mathrm{L}} \\
& \mathrm{P}_{\mathrm{X}} \mathrm{X}+\mathrm{P}_{\mathrm{cc}} \mathrm{t}_{\mathrm{cc}}+\mathrm{P}_{\mathrm{CX}} \mathrm{CX}=\mathrm{wt}_{\mathrm{em}}+\mathrm{V}
\end{aligned}
$$

The mother's total time can be divided into market paid time, $\mathrm{t}_{\mathrm{em}}$, home production time, $\mathrm{t}_{\mathrm{hp}}$, caregiving time, $\mathrm{t}_{\mathrm{mcc}}$, and leisure, $\mathrm{t}_{\mathrm{L}}$. In addition, there is implicitly a child's time constraint in that parents with young children (which we operationalize as parents with children under age 13) must have someone watching their children at all times.

$$
\mathrm{CT}=\mathrm{t}_{\mathrm{mcc}}+\mathrm{t}_{\mathrm{cc}}+\mathrm{t}_{\mathrm{scc}}
$$


CT is the total amount of time available to children. We have already defined $t_{\text {mcc }}$ as maternal child care time and $\mathrm{t}_{\mathrm{cc}}$ as non-maternal time, both of which contribute to increased levels of child services. The final term, $\mathrm{t}_{\mathrm{scc}}$, is secondary child care time in which children are being supervised but not actively engaged. For the sake of modeling ease, this secondary care time is assumed to not contribute to child services and to be provided without opportunity cost by the mother or without money cost by anyone other than the mother. If we think of $t_{\mathrm{scc}}$ as including sleep time then $\mathrm{CT}=\mathrm{T}$.

The above three constraints result in three distinct costs of a mother's time. First, there is the cost of time in the labor market, $\mathrm{w}-\mathrm{P}_{\mathrm{cc}}$, if the alternative to employment is primary care of one's own children. ${ }^{7}$ Second is when the mother is engaged in leisure or home production activities where children are not present because the children are actively engaged by an alternative caregiver. The opportunity cost of that activity's time is the price of earnings forgone plus the price of non parental child care, $\mathrm{w}+\mathrm{P}_{\mathrm{cc}}$. At other times, when children are being supervised in the background, when children are in public school or when children are old enough for self care, the opportunity cost of that activity's time is simply the wage, w. Since the cost of time is sometimes the wage, sometimes the wage plus the price of child care and sometimes the wage minus the price of child care, the wage and the price of child care must appear separately in any estimation model. ${ }^{8}$

The behavioral model described above results in time demand functions for the four different uses of time, as well as the more standard consumption good demand functions for $\mathrm{G}$ and CX. Equation 5 presents a general functional representation of the time demand functions.

\footnotetext{
${ }^{7}$ See Connelly (1992) and Ribar (1995) for models of non-maternal child care that derives the w-P $\mathrm{P}_{\mathrm{cc}}$ cost of time.

${ }^{8}$ Kimmel (1998) provides empirical justification for including separate measures for the wage and the price of care in employment equations.
} 


$$
t_{j}=f(w, P c c, V \mid Z, H, D) \quad \text { for } j=e m, h p, \text { mcc, } L
$$

Time use is related to factors reflecting the value of time, including the wage and the hourly price of non-parental child care for women with young children, the amount of nonlabor income available to the mother and preferences and institutional structure which are expected to be related to personal characteristics of the mother, Z, characteristics of the household in which she resides, $\mathrm{H}$, and characteristics of the diary day, $\mathrm{D}$.

\section{IV: Data and Estimation Strategy}

\section{1: The ATUS}

As described above, our primary goal in this paper is to examine the determinants of time spent in four activities: leisure, child care, home production and employment for mothers with children under the age of 13 living in the same household We aim to assess whether child care time behaves more like leisure or home production or alternatively, as might be expected from our discussion of Gronau's criteria for time aggregation, child care time might fall somewhere in between leisure time and home production time. Based on our model in which leisure time directly enters the utility function, while child care time and home production time enter through the production functions of CS and G respectively, we categorized the time activities included in the ATUS data into these three time uses, plus market employment time and one other category. ${ }^{9}$

\footnotetext{
${ }^{9}$ It is not essential for our estimation procedure that all 24 hours in a day be accounted for in these four time uses. The correlation among the equations is addressed through cross equation covariances, not in cross equations coefficient restrictions as would be necessary if we were accounting for all time within a 24 hour period. Solberg and Wong (1992) and Kim and Zepeda (2004) do account for all time while Kalenkoski, Ribar and Stratton (2005a, 2005b) do not. In our case, we considered not omitting the "other" category so that all time would in fact be accounted for, but then one must confront issues very similar to those discussed in text about child care as much of the "other" time, such as formal education, is neither clearly utility enhancing (i.e., leisure) nor is it merely part of a current production function. Like child care, education time is difficult to categorize in the static framework as it has a large investment component. As such, we decided to estimate equations for four uses of time via the Tobit equivalent of Seemingly Unrelated Regressions. (See Prowse (2004)).
} 
Appendix A records the full set of decisions we made in assigning the six digit time categories to our five category framework.

Our sample is comprised of female ATUS diary respondents between the ages of 18 and 65 who have children under the age of 13 living in the household, are not part of a multifamily household, and are not currently in the active duty military, in school nor unemployed. These criteria, in addition to requiring each observation to have information on the husband's wage if married with spouse present, leads to a sample size of 3064 women. Since weekdays and weekends represent very different time use patterns for many families and because the ATUS oversamples weekend days, we separate the data throughout the analysis into weekends and weekdays. ${ }^{10}$ In the end we have usable time diary information from 1445 women for weekdays and 1619 for weekend days.

Table 1 presents the average minutes spent in the four time categories for the mothers in our sample. Looking at Table 1, we see substantial differences in the time spent in our four categories between weekdays and weekends. Leisure and home production times are higher on weekends while the opposite is true for employment and child care time. It is a bit surprising that less time is spent in active caregiving by all groups on the weekend than weekday as the number of hours of employment is also substantially lower on the weekend. These differences provide suggestive evidence that time spent in child care is distinct from home production and leisure.

Table 1 also shows substantial differences in the means of child care time, home production, and employment time if one includes those women with zero time that day or not.

\footnotetext{
${ }^{10}$ In fact, weekend employment typically is referred to as nonstandard employment. Also, note that we include weekday holidays in the weekend sample so the sample is really weekends and holidays. We do this because there are very few weekday holidays in the data and but those holidays look very different from weekdays in time use patterns. Kalenkoski et al (2005b) divide their data in the same way.
} 
The substantial number of respondents with zero time use in these categories means our estimation strategy should explicitly take account of the left censoring of the time responses at zero. On the other hand, no one in the sample has zero minutes of leisure and very few have a full day of leisure so that we need not be concerned about censoring of the leisure time equation.

Further descriptive information is presented in Table 2. The top half of the table shows the expected relationship between age of the youngest child and the number of minutes spent on child care. Married mothers whose youngest child is under five spend 195 minutes in active child care on a weekday and 142 minutes on a weekend day. The number of minutes decreases substantially when the youngest child is elementary school aged, to 99 minutes on weekdays, and 61 minutes on a weekend day. The pattern is the same for unmarried mothers but the average minutes in each activity is less. Married women spent more time on home production than unmarried women, suggesting that a husband's presence increases requisite work in the home or that single mothers "contract out" more of the home production. Standards may be higher in married households and there is another person in the house for whom to produce goods. One might have hypothesized that time in home production would be less for married women as they have someone to share the home production chores but that hypothesis is not supported, at least in this cross tabulation analysis.

The bottom half of Table 2 shows the distribution of average time use by marital status and predicted wage rate categories. The middle wage category is defined as the mean predicted wage in the full sample (\$11.50) plus and minus one standard deviation (\$4.50). Thus, a low wage is a wage less than $\$ 7$ an hour and a high wage is a wage greater than $\$ 16$ an hour. ${ }^{11}$ As expected, women with high predicted wages are employed in the labor market on the diary day

\footnotetext{
${ }^{11}$ Wages are predicted using a standard two step Heckman correction. For details, see section IV. 4.
} 
for more minutes. Unmarried mothers are employed more minutes than married women, especially on weekdays for mothers in the highest wage category.

Table 2 also shows that child care time, like employment time increases with married women's wages, but the same is not true on weekdays for unmarried mothers. Those unmarried mothers with the highest wages devote less time for child care than middle wage unmarried mothers but still more than low wage unmarried mothers. Overall, however, minutes of child care move mostly in the same direction as minutes of employment, while minutes of home production and minutes of leisure move together in the opposite direction, at least on weekdays.

\section{IV.2: Empirical Model}

The evidence presented in Table 2 is merely a cross tabulation, however. A fuller understanding of the relationship among marital status, age of children, and wages requires a multivariate analysis. Our basic estimation model is a system of four linear time use equations based on the time demand equations shown in equation 4 . The estimation version of equation 4 can be characterized as:

$$
\mathrm{t}_{\mathrm{j}}^{*}=\beta_{0 j}+\beta_{\mathrm{j}}^{\prime} \mathrm{X}+\varepsilon_{\mathrm{j}} \text { for } \mathrm{j}=\mathrm{em}, \mathrm{hp}, \mathrm{mcc}, \mathrm{L}
$$

where $\mathrm{t}_{\mathrm{j}}$ * is the latent number of minutes a women would choose to spend in activity $\mathrm{j}$. The actual observed minutes, $t_{j}$ will equal zero when $t_{j} *$ is less than zero. In our sample, leisure was never zero because leisure includes sleeping. ${ }^{12}$

A tobit model is used often to account for situations like equation 6 if one is willing to assume that the $\varepsilon_{\mathrm{j}}^{\text {'s }}$ are normally distributed. In our case, in addition to accounting for the lower limit constraint, we must also account for the fact that four observed time uses come from the

\footnotetext{
12 In a few cases, leisure is constrained to 1440 minutes, the number of minutes in a day. We do not account econometrically for the upper constraint problem as it occurs so infrequently.
} 
same sample respondent. More time used in one activity certainly means less time used in some other activity. ${ }^{13}$ We assume that the $\varepsilon_{\mathrm{j}}$ terms are correlated across equations in the following way:

$$
\left(\begin{array}{c}
\varepsilon_{l} \\
\varepsilon_{m c c} \\
\varepsilon_{h p} \\
\varepsilon_{m}
\end{array}\right) \sim N\left(\left(\begin{array}{l}
0 \\
0 \\
0 \\
0
\end{array}\right),\left(\begin{array}{cccc}
\sigma_{L}^{2} & \rho_{L m c c} \sigma_{L} \sigma_{m c c} & \rho_{L h p} \sigma_{L} \sigma_{h p} & \rho_{L m} \sigma_{L} \sigma_{m} \\
\rho_{L m c c} \sigma_{L} \sigma_{m c c} & \sigma_{m c c}^{2} & \rho_{m c c h p} \sigma_{m c c} \sigma_{h p} & \rho_{m c c m} \sigma_{m c c} \sigma_{m} \\
\rho_{L h p} \sigma_{L} \sigma_{h p} & \rho_{m c c h p} \sigma_{m c c} \sigma_{h p} & \sigma_{h p}^{2} & \rho_{h p m} \sigma_{h p} \sigma_{m} \\
\rho_{L m} \sigma_{L} \sigma_{m} & \rho_{m c c m} \sigma_{m c c} \sigma_{m} & \rho_{h p m} \sigma_{h p} \sigma_{m} & \sigma_{m}^{2}
\end{array}\right)\right)
$$

This situation is analogous to Seemingly Unrelated Regression except we must use a nonlinear estimation technique to account for the lower limit constraints. Accounting for both the constraint at zero minutes and the correlation among error terms leads to our choice to estimate a system of four correlated equations, three of which are estimated as tobit equations. ${ }^{14}$

The "X's" of equation 6 include standard demographic characteristics of the mother, $\mathrm{Z}_{\mathrm{i}}$, characteristics of the household, $\mathrm{H}_{\mathrm{i}}$, characteristics of the diary day, $\mathrm{D}_{\mathrm{i}}$, and three predicted price of time measures. We discuss each set of variables briefly in turn. The vector $\mathrm{Z}_{\mathrm{i}}$ includes variables such as age, education, urban/rural residence, Southern/non-Southern residence, Nonwhite/White, and Hispanic/non-Hispanic. These variables may reflect differences in time preferences and also, in the case of residence variables, differences in the price of commodities

13 This is not necessarily the case since the total time is not accounted for but our four categories account for almost all the time with the mean sum of the four time uses being 1413 minutes out a possible 1440. Thus, there should be a strong connection between increased time use in one category and decrease in at least one of the other three categories.

${ }^{14}$ Our estimation procedure is very similar to that used by Kalenkoski, Ribar and Stratton (2005a, 2005b) except we have four uses of time and they model three. Our fourth equation is estimated via OLS. 
and structural demands on one's time. For example, urban dwellers may spend more or less time commuting to work and traveling to shopping. Southern dwellers may have more yard work etc.

We do not have strong theoretical predictions about the pattern of the effect of these demographic variables, nor are there many previous empirical studies of child care versus home production time to inform our expectations. There have been many studies of the determinants of weekly or annual hours of work and paid work hours has always been less affected by demographics than the labor force participation equation so we do not expect to find large differences across demographic groups in the uses of time.

The variables included in characteristics of the household, $\mathrm{H}$, include Married Spouse Present/ Not Married or No Spouse Present, Husband's Earnings (if Married Spouse Present, zero otherwise), the presence of other adults in the household (persons over 17 years of age who are not the woman nor her spouse), and five counts of the number of children in the household aged 0 to 2, 3 to 5,6 to 9, 10 to 12 , and 13 to 17 . Other studies simply have included the total number of children and the age of the youngest child but we expect that children of different ages contribute differently to the time demands on mothers' time. Certainly, Table 2 shows substantial time use differences by age of the youngest child. Studies of the effect of the presence of children on mother's employment have found differences between having a 0 to 2 years old versus having a 3 to 5 year old. One reason for this difference is that many families view preschool as an educational investment in their children, not just as supervised time that facilitates women's employment, but still, consumed preschool does free up the mother's time while the children are at school. Six to 9 year olds are in school much of the day but they are usually not left alone before and after school, while 10 to 12 year olds are left alone often. Teenagers bring their own set of time and money demands which may affect mothers' 
employment (this has sometimes been shown for school aged children as well.) Teenagers also could contribute time (at least potentially) to household child care and home production, freeing up maternal time for employment and leisure. ${ }^{15}$ Connelly, DeGraff and Levison (1996) found strong evidence of this in urban Brazil but the results for the United States have been weaker. However, sibling care may be used to facilitate mothers’ leisure activities rather than employment, which would not show up in employment-based studies. The presence of other adults in the household may affect mothers' time use if household members truly behave as a cohesive unit, but even in that case, the direction of the effect is not clear. A coresiding adult could contribute income to the household, thus freeing up the mother to do more of the child care, or could contribute child care and home production time, freeing up the mother for more employment time. The coresiding adult may also increase home production time, especially if the coresiding adult is an elderly relative who requires care.

The predictions about the effect of marriage and husband's earnings in our model mostly are ambiguous. The presence of the spouse should reduce child care and home production time to the extent that he participates in these tasks, but the demand for home production tasks also increases. We saw in Table 2 that the presence of the spouse is correlated with greater home production time. In addition, controlling for husband's earnings, married women have higher rates of employment, which would lead to increased employment time and reduced child care time. The higher rates of employment could be due to positive assortative mating or the husband's' facilitating maternal paid employment, even if he is not directly providing child care. His presence may provide another set of relatives to draw on for emergency care or his time simply may add flexibility to the woman's time choices, such that employment is easier to

\footnotetext{
15 Mothers who have only teenagers at home are excluded from this analysis so the teenagers in our sample are all potential babysitters as they all have younger (12 years of age or younger) siblings.
} 
sustain. Assuming husband employment time is exogeneous (which is, in the dawn of the $21^{\text {st }}$ century still not a bad assumption), results in husband's earnings playing the role of nonlabor income in the model. Nonlabor income could be expected to reduce all "work" time (employment and home production), and should increase leisure time, but the effect on child care depends on the weighting of the "work" versus the "consumption" components of child care time. Higher nonlabor income may also mean a bigger house or more "stuff” to take care of, so even the effect on home production is ambiguous.

We control for the season of the year the diary information was collected with a dichotomous variable indicating if the diary month were June, July or August. In preliminary work we included a dummy for each season but found that the only significant differences in time use were observed in summer.

The last three regressors represent components of the price of time. The price of time is expected to affect all uses of time and so is included as determinants of leisure, child care time, home production and employment. As discussed in Section 3, women with children under 12 sometimes face an additional cost of their time beyond their hourly wage which is represented by the price of child care. For very young children, supervision is necessary at all times so that an hour of mother's time in the labor market means she receives her wage but she may have to pay for an hour of child care. On the other hand, an hour of child care provided by the mother means that she does not have to pay for child care that hour. Leisure and home production are sometimes engaged in simultaneously with supervisory child care. For these uses of time, the price of child care is not relevant, but there are uses of adult leisure time for which non parental child care is used and the same can be expected for some home production time (try painting the 
bedroom with an awake 2 year old at home). Thus, the price of child care is included in all four time use equations.

\section{IV.3: Preliminary Estimations}

All the variables used as determinants of time use described above except for the three time cost variables come directly from the ATUS. The three price of time variables, on the other hand, are predicted values obtained from preliminary estimation. The predicted wage is obtained, as is typical, by estimating a sample-selection-corrected wage equation using ATUS data. We would have liked to generate the price of child care the same way but the ATUS data do not include child care expenditure information. ${ }^{16}$ Instead, we used the fourth wave of the 2001 Panel of the Survey of Income and Program Participation which was administered between September and December 2002. Employed women with children under the age of 5 were asked about their expenditure on child care for their youngest child. In addition, employed women with children between the ages of 6 and 14 were asked about their expenditure on child care for their youngest child in that age range. We eliminated those whose youngest child was 13 or 14 and those who were either currently in the military, in school, or unemployed. We used the resulting sample to estimate the price of child care for children age 5 or under and separately for children between the ages of 6 and 12. We could have then averaged the 0 to 5 year old price of child care and the 6 to 12 price of child care but we have chosen to keep them separate since the availability of five or six hours of school time which doubles as non-parental child care time makes child care for 6 to 12 year olds very different from that for children 5 and under. The procedure we used to estimate the hourly price of child care is a standard bivariate selection correction model (described by Tunali (1986) and used by Connelly and Kimmel (2003a,

\footnotetext{
${ }^{16}$ Another option is to use exogenous local child care price measures but those data are unavailable nationally for our time period.
} 
2003b)). Using this procedure, we predicted the weekly expenditure on child care correcting for the self selection of being both employed and paying for care. The child care price equation is

$$
P_{\mathrm{cci}}=\alpha_{0}+\alpha Z_{\mathrm{i}}+\theta_{1} \lambda_{1 \mathrm{i}}+\theta_{2} \lambda_{2 \mathrm{i}}+\mathrm{u}_{\mathrm{i}}
$$

where $\lambda_{1}$ and $\lambda_{2}$ correct for the sample selection of only employed mothers who are paying for care being included in the estimating sample. Having estimating the model using SIPP data, we then used the dot product of the predicted coefficients $\alpha$ and the $\mathrm{Z}_{\mathrm{i}}$ 's from the mothers in the

ATUS sample. This dot product can be interpreted as the predicted weekly expenditures, unconditional on paying of care and being employed. ${ }^{17}$

\section{4: Identification}

Estimating multi-step models such as these requires strict attention to equation identification. We confront these issues at two levels. At the first level, the wage and the two prices of child care are estimated in two step procedures, first estimating sample selection terms and then estimating the wage or price of child care with the sample selection term included as an explanatory variable. While theoretically one can estimate this type of sample selection model identifying off of the functional form only, most researchers feel more comfortable with identification coming from exclusions, i.e., variables that are thought to affect the dichotomous choice that are not expected to affect the wage or the price of child care. In our case, we include a number of potential identifiers in the dichotomous choice equations. Variables included in the reduced form employment and pay for care equations that are not included in the price of child care equation include second order terms of age and education, age times education, a dichotomous variable indicating the presence of other adults in the household (PRESENCE), the

\footnotetext{
${ }^{17}$ As is well known, incorporating generated regressors in this way produces biased standard errors. Due to the complexity of our model, we have not corrected the estimated standard errors for this bias.
} 
maximum TANF award in the state of residence for a family of three (TANFAMT), and their state’s per capita medicaid budget (STMEDICAID). Variables included in the reduced form employment equation that are not included in the wage equation include all the variables listed above plus six state level child care variables: a dichotomous variable if the state provides a tax credit for child care expenses (STCCCREDIT), a dichotomous variable if the state requires that child care teachers have a minimum level of training (MINTRAIN), a dichotomous variable if the state requirement for child/teacher ratio for infants is 4:1 or better (INFANTSZ), a dichotomous variable if the state requirement for child/teacher ratio for four year olds is 10:1 or better (4YROLDSZ), the number of licensed child care centers per child under age 5 in the state (LICCENTERS), and the number of licensed day care homes per child under age 5 in the state (LICHOMES).

The second level of concern with identification comes from the use of three generated regressors in our four time use equations. Both the predicted wage and the two predicted child care price measures rely on preliminary equation estimation. For the wage, the preliminary estimation involves a sample-selected wage regression that includes one variable not also appearing in the time use equation. Our identifying variables are state level regressors thought to affect the individual's wage but not their time allocation choices:a dummy variable indicating the existence of a state minimum wage that is higher than the federal minimum wage (STATEMIN), the state's unemployment rate (UNEMPLR), and the state's female labor force participation rate (STLFPR). Additionally, we use age-squared as another potential identifier. For the two child care price measures, identification requires that at least one variable appear in the child care price equations that does not also appear in the time use equation. These identifying variables are the six variables listed above that reflect state child care regulations and 
the three state labor market variables just listed that serve as identifiers of the wage equation.

\section{IV.5: Descriptive Statistics for All Regressors}

Table 3 presents the descriptive statistics for all the right hand side variables for both the weekday sample and the weekend sample. Note that there are 1445 observations in the weekday diary sample and 1619 in the weekend sample. The wage is presented in its natural logarithm form. The husband's earnings is reported in thousands of dollars. There are no substantive differences in these variables by weekday/weekend status so we describe the means for the weekday sample only. Sixty-two percent of the women in the sample are married and they are on average, nearly 36 years old with 13.5 years of education. There is an over-sampling in the ATUS of minority populations, as reflected in the high percentages nonwhite and hispanic (18.8 percent and 15.8 percent respectively). Eighty-two percent reside in urban areas and fully onethird reside in the south. Fully twenty percent of the women report having another adult (other than a husband) residing in the same house. Finally, approximately one-fourth of the diaries were recorded in the summer reflecting the fact that ATUS data is collected evenly throughout the calendar year.

\section{IV: Results}

We will not discuss results from instrumenting regressions in text, but those results can be found in appendix tables available from the authors. The results are very similar to those reported in (self reference 2003) which used SIPP data from the early 1990's. For our jointlyestimated four time use equations, we will discuss first the weekday results then the weekend 
results. Within each, we discuss results by variable category, and for the price of time variables, we include a discussion of elasticities.

\section{1: Results for Weekday Observations}

Demographic variables--Table 4a presents the estimated marginal effects of minutes spent in the four time uses on weekdays while Table $4 \mathrm{~b}$ presents the results for weekends. ${ }^{18}$ A quick glance down the columns confirms the cross tabulation findings of Table 2 that child care is distinct from both leisure and home production. For example, the effect of age on time use (recall we are controlling for wage levels and number of children) is to increase home production but decrease child care time. Minutes of leisure are unaffected by age, ceteris paribus. Similarly, higher husband's earnings has no effect on leisure while it increases both maternal child care time and home production time. This is consistent with the hypothesis discussed above that higher income families demand higher levels (either quality or quantity) of active child care and home production time and these higher levels require more time inputs.

Household variables--One key set of variables that we are interested in are the household configuration variables, identified in equation (6) as $\mathrm{H}_{\mathrm{i}}$. As we expected, having very young children (aged 0 to 2) increases women's time in child care on weekdays substantially. Each additional child in that age range results in 70 extra minutes of child care time. That extra time per infant comes mostly from reduced employment time (38 minutes) but leisure time is also

\footnotetext{
${ }^{18}$ The values in Table $4 \mathrm{a}$ and $\mathrm{b}$ represent the derivative of $\mathrm{t}_{\mathrm{j}}$ with respect to the independent variable. To obtain the derivative of $\mathrm{t}_{\mathrm{j}}$ we multiplied the estimated coefficients, $\beta_{j}$, by the probability of a nonzero outcome. The marginal effects for leisure time use are the same as the estimated coefficients since none of the respondents reported zero hours of leisure so the equation is estimated via OLS. These probabilities were evaluated at the mean for all regressors. Appendix Tables B1 and B2 report the estimated coefficients and the standard errors on which Tables $4 \mathrm{a}$ and $4 \mathrm{~b}$ are based.
} 
reduced by 31 minutes. Home production time on weekdays is not affected by the number of very young children. Older children (aged 3 to 5, 6 to 9, and 10 to 12) have very similar effects on women's time. Employment is no longer reduced significantly except for 10 to 12 year olds. But children of this age range add almost an exact half hour to child care time, and children in the older two child age categories also add to home production time. Since the time is not coming from employment it comes from leisure time, with leisure time reduced about 30 minutes per child. Teenagers, on the other hand, seem to have no effect on mothers' time during the week. Weekends are different in this regard, as we will see in later discussion. ${ }^{19}$

Married mothers spend less time in child care and leisure and more time in household production. Finally, the last household characteristic variable is the presence of other adults in the household. Some of these adults are providing child care as mothers' minutes of child care on weekdays are reduced 31 minutes by the presence of another adult (excluding her husband if married). Kalenkoski, Ribar and Stratton (2005b) found similar effects of other adults present on mother’s weekday child care both primary and passive.

Diary Day Characteristics--The season that the diary was collected affects time use, with summer being a time of increased leisure (about 43 minutes a day more) and less child care time. It is extremely interesting that summer should affect these two time uses in such opposite ways. This combined with the other results on child care time versus other time uses seems to indicate that self reported child care time is more rigid time related to regular weekday routines and that summer time loosens our routines, increasing the time that is categorized as leisure and reducing time that is categorized as child care time. Kalenkoski, Ribar and Stratton (2005b), using the

\footnotetext{
${ }^{19}$ On the weekend, teenagers seem to be providing some babysitting, thus reducing their mothers' child care time, and they increase the mothers' employment time. This could be because they are available to babysit or because they increase the family's need for money income.
} 
same data, also find that summer substantially reduces women's weekday primary child care time. They find that women's weekday passive child care time is increased in the summer by about as many minutes as primary child care time is reduced.

Price of Time Variables-In the standard labor/leisure model, an increase in the wage is expected to increase hours worked and decrease leisure, assuming that the substitution effect is greater than the income effect, as is typically the case for women. In other words, the push towards increased work due to the rising opportunity cost of leisure dominates the push towards increased leisure demand due to rising income. This is exactly what we find using our measure of leisure time. But if child care time had been included in leisure, we would have found a much smaller effect. Instead, an increase in the wage increases child care time. This result is very robust to specification changes and is true whether we include mothers with children less than 18 years of age or as reported here, mothers with children under 13 . We believe that this result comes from a strong income effect on demand for high quality of child care and that high quality child care takes more maternal time rather than more purchased child resources. Note that this contradicts the finding of Hallberg and Klevmarken (2003) who find that own wages do not affect child care time.

A higher price of child care for children aged 0 to 5 increases the amount of maternal child care time as one would expect from an own price effect. Recall that the price of child care for children 0 to 5 is only applied to those women with children in that age range. A higher price of child care also reduces employment hours, a finding which is consistent with the large body of literature which has found negative effects of the price of child care on women's employment. ${ }^{20}$ The price of child care for older children is found to have a significant negative effect on the

\footnotetext{
${ }^{20}$ See, for example, Kimmel (1998), Ribar (1992), and Connelly (1992).
} 
utilization of paid child care for school-aged children, but has no effect on weekday employment time of women with children in that age group. This suggests that there exists more flexibility in choices of child care options for school-aged children, including possibly free after-school care and self-care.

Table 5 presents the elasticities evaluated at the means implied by the marginal effects in Table 4a. All the elasticities except for child care time are less than one in absolute value, implying that these three uses of time, leisure, home production and market work are relatively insensitive to the price of time. The elasticity of child care time with respect to the mother's hourly wage is not only positive but greater than one, meaning that mother's child care time is elastic with respect to the largest component of the opportunity cost of her time. Employment time with respect to wage is also positive with an elasticity substantially greater in absolute value than either home production time or leisure. ${ }^{21}$ A $10 \%$ increase in the wage leads to an $8 \%$ increase in time spent in weekday employment and an 12\% increase in time spent in weekday child care. The elasticities with respect to the price of child care for preschool children have the inverse structure we might have expected given the work hours wage effects, and are much smaller. A $10 \%$ increase in the price of child care is predicted to reduce mother's weekday employment hours by $1.2 \%$ and increase child care time by $1.4 \%$.

Correlation Between Time Uses -The bottom of table 4a shows the estimated correlations between the four uses of time. Child care and home production are positively correlated though the correlation is very small. The tradeoff between working and home production is almost equal to the tradeoff between working and leisure, while the tradeoff between working and child

\footnotetext{
21 This estimate of the wage elasticity of paid work hours is within the range of results found by other researchers. See, for example, Mroz (1987) and Kaufman and Hotchkiss (2003).
} 
care is substantially lower. This is still further evidence that child care time is not equivalent to either home production or leisure.

\section{2: Results for Weekend Observations}

Demographic variables -Table 4b summarizes the results of the four time use models for weekend days. ${ }^{22}$ Instead of commenting here on all the marginal effects, we concentrate on differences between weekdays and weekends. While the demographic variables follow very similar patterns on weekend days as weekdays, there are fewer significant differences. For example, husband's earnings is less a predictor on time use for weekends than weekends and married mothers do not differ at all from unmarried mothers on the weekends. Similarly, Hispanic mothers do not differ from non-Hispanic mothers on weekends, nor are there differences by race. Urban mothers having significantly more leisure time on a weekend day while the effect of urban residence on leisure is insignificant weekdays.

Education is one variable that seems to have a much greater effect on weekend than weekday time. Mothers with one more year of education have 19 more minutes of leisure on the weekend, 9 fewer minutes of child care and 11 fewer minutes of home production. However, employment time is unaffected by mother's education once other relevant factors are controlled. Household variables -Focusing on household variables reveals interesting weekend day differences in time use. The presence of infants decreases women's leisure more on the weekend than during the week: 47 minutes fewer on the weekend per child while only 31 minutes fewer on the weekday. Child care time for an additional infant increases on a weekend slightly less than on a weekday (59 minutes versus 70 minutes, respectively) while the child care time for older children is substantially less on weekends than weekdays. Kalenkoski, Ribar and

\footnotetext{
${ }^{22}$ Coefficient estimates appear in Appendix Table B2.
} 
Stratton (2005b) present similar results comparing weekdays and weekends in terms of primary child care time. Here, the time on the weekend does not seem to be made up by passive care by mothers but by primary and passive care by fathers and other adults.

Another interesting difference between weekends and weekdays comparing Tables 4a and $4 \mathrm{~b}$ is the effect of teenagers and other adults on mother's time use. As we discussed above, teenagers have no effect on mothers' time use on weekdays. On weekends, however, teenagers do seem to be contributing to family child care, reducing the minutes of maternal child care by 21 minutes and increasing mothers’ employment time by nine minutes. Having another adult in the household (other than a husband) has a substantial effect on mothers' employment hours and child care hours on the weekend. Mothers with another adult in the household work 21 more minutes a day and engage in 19 fewer minutes a day of child care. Some of the "other adults" are own children who are 18 years of age or older so that they, like the younger teenagers, contribute time to the family on weekends but not on weekdays.

Diary Day Characteristics -We saw earlier that in summer, leisure time was substantially higher and child care was slightly lower. The effect of summer is much smaller on the weekends. Leisure time increases by 24 minutes on a summer weekend day (relative to a weekend day any other time in the year), whereas on weekdays, leisure was increased by 43 minutes. In addition, child care time, which was affected by the season on weekdays, is unaffected by the season on weekends. Again it appears that child care time is structured time. Weekends like summer are less structured so that weekends in the summer are less different than weekdays than during other seasons. It may be the structured nature of child care time that causes it to respond in many ways more like work than either home production or leisure. 
Price of Time Variables - Recall that on weekdays, a higher hourly wage decreased leisure and home production time while increasing child care and employment. On weekends, a higher hourly wage had the same effects except on home production time, which now increases with wages. Why do mothers with higher wages do more rather than less housework on the weekend? Partly, we may be observing the shifting of time from weekdays to weekends. Some home production tasks, such as laundry, housecleaning and grocery shopping, are fungible throughout the week, while others such as meal preparation are less fungible. Higher wage mothers are also working more hours and doing more hours of child care on the weekend than lower wage women. These results seem to support of the hypothesis posited by Hamermesh and Lee (2004), namely that high income women face a significant time crunch because of the high value of their time.

The price of child care for young children is a significant positive predictor of minutes spent in employment on the weekend (for mothers of young children) but does not affect child care time or home production time as it did on weekdays. This may be related to a greater use of teenagers, other adults, and husbands (if married) for weekend employment than for weekday employment, so that higher prices of child care induce mothers to move employment from weekdays to weekends. The sign on the derivative of the price of child care for children 6 to 12 with respect to to child care time is also reversed on the weekend, indicating that a higher price of child care for school age children reduces weekend child care time (perhaps because employment is increased, though the employment coefficient is measured imprecisely).

Table 5 records the elasticities of time use with respect to the price of time measures. The magnitudes of the elasticities are similar on weekends to weekdays except the effect of the price of child care for preschoolers on child care time which is not significantly different from 
zero on the weekend. The elasticities with respect to hourly wage are similar across the days of the week except, as we discussed above, the sign of the effect of wages on home production is reversed. As with weekdays, all time measures are inelastic with respect to the wage and prices of care except child care time's elastic responsiveness to changing wages.

Correlation Between Time Uses -The correlation of unobservables in time determination are all negative on the weekend, indicating the time in one category competes with time in another category. Since weekends seem to be the time to catch up on home production chores, leisure and home production are more strongly negatively correlated on weekend days than on weekdays, while working and home production are less negatively correlated. Child care time and working are also much less negatively correlated since others seem to be doing more of the child care on the weekends. Considering weekday and weekend cross-equation correlations, eleven of the twelve estimated correlations are statistically significant, providing strong justification for joint equation estimation.

\section{VI: Summary}

We began the paper with the question, "Is the time mothers spend in child care best categorized as home production time or leisure?” Our theory suggested that child care time should not be aggregated with leisure as a substantial portion of child care time is part of the production function of child services rather than a source of immediate utility. Thus, we hypothesized that child care would appear as an intermediary between leisure (due to some utility generating aspects of child care) and home production. As expected, the empirical results

presented here strongly suggest that aggregating child care with leisure or with home production would be inappropriate for reasons first outlined by Gronau (1977). Child care time does not 
behave like either leisure or home production in its response to demographic differences, diary day or predicted prices of time. But somewhat surprisingly, child care does not take the middle road between leisure and home production. Instead, child care time often behaves quite distinctly from both of these time uses. Indeed, we found that child care often behaves like employment. In particular, higher maternal wages increase both child care time and employment time, the former more so than the latter.

Should we be so surprised by child care time’s determinants? In other writings, self reference argued that child care is "work" in the sense that it is engaged in for the reward much more so that the process utility. Child care and employment both share a strong investment component. Why else do salaried employees often work more hours than hourly employees, if not to invest in their future wage growth? Child care time often is devoted to the production of child services, the benefits of which will not be reaped for many years to come. In addition, child care time may be less fungible within the week than home production. Children need to be put to bed every night and homework needs to be supervised most weeknights, but the laundry and washing the kitchen floor can wait until the weekend. Thus, we can understand the pattern that emerges from the comparison of weekdays and weekends as shown in Table 1, that child care time is lower on the weekends than weekdays but home production and leisure are greater on the weekends.

In part, our findings on child care may be driven by our choice to define child care time as primary child care activities, thereby excluding activities where children are present but caregiving is not reported as the primary activity. It may be that responders naturally divide their time with children into that which generates direct utility and that which is "work." It appears that the time that generates utility may be classified by the activity in which the mother 
is engaged rather than child care. Still it is somewhat surprising that the split is so stark since primary child care activities include playing with children, reading to children and talking with children.

Concerning the demographic determinants of child care time, married women with spouses present differ significantly from nonmarried women in their weekday time use. On weekends, however, Married Spouse Present is not a significant predictor of any of the time uses. Married women with higher husband's earnings spend less time employed and more time on child care on both weekdays and weekends and spend more time in home production on weekdays. Similarly, race and Hispanic origin were shown to affect time use on weekdays but not on weekends.

One of the contributions this study makes to the literature on mothers' time use is the estimation of time use equation estimates that include wages and the price of child care, thereby facilitating direct discussion of policy implications. Predicted wages and the price of child care all have some significant effects on time use decisions. Higher wages lead to more time in employment and more time in child care on both weekdays and weekends. A higher price of child care for young children increases the amount of maternal child care time and reduces employment time on weekdays. On weekends, the only significant effect is the price of care for young children on employment time. Teenagers and other adults in the household seem to lend time to mothers on weekends in ways that they did not during the week.

We have presented a substantial number of derivatives given the four uses of time, the necessary distinction between weekdays and weekends and the large number of demographic, household and price of time variables. What big picture lessons can we take away from this analysis? Firstly and most importantly, we have provided convincing evidence for other 
researchers of the importance of treating child care as a distinct time usage. Secondly, our results show that researchers must think carefully about the movement of time across days of the weeks and across seasons. Some tasks must be done at a specific time each day while others are fungible across the week and even across the year. Additionally, marital status is of sufficient importance to merit sample stratification in future research. Finally, high wage mothers appear particularly time pressed in our analysis. They spend more time on child care and employment during the week with less time for leisure and home production. On the weekend, they spend more time in home production as well as more time on child care and employment. This is suggestive evidence of a time crunch (in a sense, self-chosen) that requires further investigation. $^{23}$

\footnotetext{
${ }^{23}$ See Hammermesh and Lee (2003) for a cross national comparison of time crunch.
} 


\section{References}

Apps, Patricia. 2003. “Gender, Time Use and Models of the Household,” IZA Discussion Paper No. 796.

Apps, Patricia and R. Rees.2002. "Household Production, Full Consumption and the Costs of Children,” Labour Economics, 8, Pp. 612-648.

Apps, Patricia and R. Rees. 1999. “Individual vs. Joint Taxation in Models with Household Production,” Journal of Political Economy, 107, pp. 393-403.

Becker, Gary. 1965. “A Theory of the Allocation of Time,” Economic Journal, 75, pp. 493515.

Bianchi, Susan. 2000. Maternal Employment and Time with Children: Dramatic Change or Surprising Continuity? Demography 37, pp. 401-414.

Bianchi, Susan, Vanessa Wight and Sara Raley. 2005. "Maternal Employment and Family Caregiving: Rethinking Time With Children in the ATUS,” unpublished paper prepared for the ATUS Early Results Conference, December.

Bryant, W. Keith, and Cathleen Zick. 1996. “An Examination of Parent-Child Shared Time,” Journal of Marriage and the Family, 58, pp. 227-237.

Connelly, Rachel. 1996. "Comments on the Fertility/Employment Interaction" Population and Development Review, 22.

Connelly, Rachel, Deborah DeGraff and Deborah Levison, 1996. "Women's Employment and Child Care in Brazil" Economic Development and Cultural Change, 44 (3), pp. 619-56.

Connelly, Rachel and Jean Kimmel. 2003a. "The Effect of Child Care Costs on Employment and Welfare Recipiency of Single Mothers,” Southern Economic Journal,69 (3), pp. 498-519.

Connelly, Rachel and Jean Kimmel. 2003b. "Marital Status and Full-time/Part-time Work Status in Child Care Choices,” Applied Economics, 2003, 35(7), pp. 761-77.

Craig, Lynn. 2005. “How Do They Do It? A Time Diary Analysis of How Working Mothers Find Time for the Kids,” Unpublished working paper (January).

Folbre, Nancy, JayoungYoon,, Kade Finnoff, Allison Sidle Fuligni. 2005. "By What Measure? Family Time Devoted Children in the United States;” Demography, 42( 2), pp. 373-90.

Graham, John and Carole Green. 1984. "Estimating the parameters of a Household Production Function with Joint Products,” Review of Economics and Statistics, 66, pp. 277-283.

Gronau, Reuben. 1977. "Leisure, Home Production and Work-the Theory of the Allocation of Time Revisited,” The Journal of Political Economy Vol. 85, No. 6 (December), pp. 10991124. 
Gronau, Reuben and Daniel Hamermesh. 2004. "Time vs. Goods: the Value of Measuring Household Production Technologies,” unpublished working paper.

Hallberg, Daniel and Anders Klevmarken. 2003. “Time for Children: A Study of Parents' Time Allocation,” Journal of Population Economics, Vol. 16, pp. 205-226.

Hamermesh, Daniel S., Harley Frazis, and Jay Stewart. 2005. "Data Watch: The American Time Use Survey,” Journal of Economic Perspectives (Winter).

Hamermesh, Daniel and Jungmin Lee. 2003. “Stressed Out on Four Continents: Time Crunch or Yuppie Kvetch?” NBER Working Paper Series, Working Paper 10186, December.

Howie, Peter, John Wicks, John M. Fitzgerald, Douglas Dalenberg, Rachel Connelly. Forthcoming. "Mothers' Time Spent in Spent in Care of Her Children and Market Work: a Simultaneous Model with Attitudes as Instruments," Applied Economic Letters.

Jacobsen, Joyce P. And Peter Kooreman. 2004. “Timing Constraints and the Allocation of Time: the Effects of Changing Shopping Hours Regulations in The Netherlands,” IZA DP 1309.

Kalenkoski, Charlene, David Ribar, and Leslie Stratton. 2005a. "Parental Child Care in Single Parent, Cohabiting, and Married Couple Families: Time Diary Evidence from the United Kingdom,” forthcoming in the American Economic Review Papers and Proceedings (May).

Kalenkoski, Charlene, David Ribar, and Leslie Stratton. 2005b. "Parental Child Care in Single Parent, Cohabiting, and Married Couple Families: Time Diary Evidence from the United States and the United Kingdom,” unpublished manuscript.

Kaufman, Bruce E. and Julie L. Hotchkiss. 2003. The Economics of Labor Markets, $6^{\text {th }}$ edition. Toronto: South-Western Press, 765 pages.

Kim, Jongsoog and Lydia Zepeda, 2004. "When the Work Is Never Done: Time Allocation in US Family Farm Households,” Feminist Economics 10(1), pp. 115-39.

Kimmel, Jean. 1998. "Child Care as a Barrier to Employment for Married and Single Mothers.” The Review of Economics and Statistics 80(2), pp.287-299.

Klevmarken, N. Anders. 2004. "Estimates of a Labour Supply Function Using Alternative Measures of Hours of Work." IZA DP No. 1035, www.iza.org/iza/en/webcontent/ events/timeuse/klevmarken.pdf.

Kooreman, Peter and Arie Kapteyn, 1987. “A Disaggregated Analysis of the Allocation of Time within the Household,” The Journal of Political Economy, 95, pp. 223-249.

Mroz, Thomas. 1987. "The Sensitivity of an Empirical Model of Married Women's Hours of Work to Economic and Statistical Assumptions,” Econometrica, 55 (4) July, 765-99. 
Nock, Steven and Paul Kingston. 1988. “Time with Children: The Impact of Couples’ Work-Time Committment.” Social Forces, 67, pp. 59-85.

Presser, Harriet B. 2003. Working In a 24/7 Economy. New York: Russell Sage Foundation.

Prowse, Victoria. 2004. "Estimating Time Demand Elasticities Under Rationing,” Economics Papers Series \#2004-W22, Economics Group at Nuffield College, University of Oxford.

Reimer, Cordelia. 2002. "Parents' Work Time and the Family," The Economics of Work and Family, Jean Kimmel and Emily Hoffman, editors. Kalamazoo, MI: W. E. Upjohn Institute for Employment Research, pp. 71-104.

Ribar, David. 1995. “A Structural Model of Child Care and the Labor Supply of Married Women.” Journal of Labor Economics 13(3), pp. 558-597.

Ribar, David, 1992. "Child Care and the Labor Supply of Married Women: Reduced Form Evidence,” Journal of Human Resources, 27 (1) Winter, 134-65.

Robbins, Lionel. 1930. “On the Elasticity of Demand for Income in Terms of Efforts,” Economica 10, pp. 123-29.

Robinson, J. and G. Godbey, 1997. Time for Life: the Surprising Ways Americans Use Their Time (Pennsylvania State University Press State College, State College Pennsylvania).

Sandberg, J. and S. Hofferth, 2001. Changes in Children’s Time with Parent, U. S. 1981-1997, Demography, 38, pp. 423-436.

Smeeding, Timothy. 1997. "Time and Public Policy: Why do We Care and What Instruments are Needed?” prepared for the MacArthur Network on the Family and the Economy "Time Use, Non-Market Work and Family Well-Being.”

Solberg, Eric J. and David C. Wong. 1992. "Family Time Use: Leisure, Home Production, Market Work, and Work Related Travel,” The Journal of Human Resources, Vol. 27, No. 3 (Summer), pp. 485-510.

Tunali, Insan. 1986. “A General Structure for Models of Double-Selection and an Application to a Joint Migration/Earnings Process with Remigration,” Research in Labor Economics. Volume 8 (Part B), Greenwich, Conn., and London: JAI Press, 235-83.

Van den Brink, Henriette Maassen and Wim Groot, 1997. “A Household Production Model of Paid Labor, Household Work and Child Care,” De Economist, 145, pp. 325-343. 
Table 1: Average Minutes Spent per Day on Leisure, Child Care, Home Production and Employment for Women with Children Less than 13 Years of Age*

\section{Dependent Variables}

Minutes of child care (including zeros)

Minutes of child care (excluding zeros)

Minutes of employment (including zeros)

Minutes of employment (excluding zeros)

Minutes of home production (including zeros)

Minutes of home production (excluding zeros)

Minutes of leisure

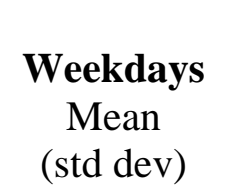

Sample size

121.044

(131.28)

1786

156.090

(129.43)

1385

242.873

(249.63)

1786

440.824

(160.65)

984

193.023

(165.05)

1786

205.814

(162.53)

1675

842.052

(217.37)

1786
Weekends

or Holidays

Mean

(std dev)

Sample size

82.001

(118.79)

1959

135.929

(127.45)

1131

58.618

(153.25)

1959

306.904

(204.84)

292

253.572

(178.68)

1959

265.351

(170.55)

1543

1024.706

(215.02)

1619

\footnotetext{
* Each cell contains the variable mean, standard deviation, and number of observations.
} 
Table 2: $\quad$ Average Minutes of Time Use by Age of the Youngest Child, Marital Status, Predicted Wage Rate and Weekend versus Weekday

\begin{tabular}{|c|c|c|c|c|c|c|}
\hline & \multicolumn{3}{|c|}{ MarriedSpouse Present } & \multicolumn{3}{|c|}{ Not Married/No Spouse Present } \\
\hline & \multirow{2}{*}{$\begin{array}{l}\text { Youngest } \\
\text { Child } 0 \text { to } 5\end{array}$} & \multirow{2}{*}{$\begin{array}{r}\text { Youngest } \\
\text { Child } 6 \text { to } 12\end{array}$} & & \multicolumn{3}{|c|}{ Youngest Child Youngest Child } \\
\hline & & & & 0 to 5 & 6 to 12 & \\
\hline \multicolumn{7}{|l|}{ Weekday } \\
\hline Minutes in market & 199.5 & 262 & & 201.6 & 258.2 & \\
\hline Minutes in child care & 195.1 & 98.7 & & 157.1 & 76.9 & \\
\hline Minutes in home production & 217.1 & 221.5 & & 153.8 & 167.1 & \\
\hline Minutes in leisure & 802.6 & 827.5 & & 885.6 & 874.9 & \\
\hline \multicolumn{7}{|l|}{ Weekend } \\
\hline Minutes in market & 45.5 & & & \multirow{2}{*}{$\begin{array}{r}66.4 \\
102.1\end{array}$} & \multicolumn{2}{|l|}{75.7} \\
\hline Minutes in child care & \multirow{2}{*}{$\begin{array}{l}141.9 \\
254.5\end{array}$} & 60.8 & & & 47.3 & \\
\hline Minutes in home production & & 288.9 & & 228.1 & 226.9 & \\
\hline Minutes in leisure & 989.4 & 1030 & & 1025.4 & 1075.8 & \\
\hline & \multicolumn{3}{|c|}{ Married Spouse Present } & \multicolumn{3}{|c|}{ Not Married/No Spouse Present } \\
\hline & Low Wage & Middle Wage High Wage & & Low Wage $\quad 1$ & Middle Wage $\quad$ & High Wage \\
\hline \multicolumn{7}{|l|}{ Weekday } \\
\hline Minutes in market & 150.4 & 234.4 & 267.2 & 166.3 & 254.7 & 393.2 \\
\hline Minutes in child care & 131.3 & 132.7 & 150.1 & 67.6 & 104.2 & 91.3 \\
\hline Minutes in home production & 256.6 & 219.1 & 201.1 & 167.5 & 156.7 & 136.8 \\
\hline Minutes in leisure & 881.1 & 826.0 & 786.7 & 945.2 & 877.3 & 766.4 \\
\hline \multicolumn{7}{|l|}{ Weekend } \\
\hline Minutes in market & 42.7 & 54.0 & 50.8 & 59.0 & 76.9 & 51.8 \\
\hline Minutes in child care & 82.9 & 91.0 & 120.8 & 51.0 & 60.5 & 82.3 \\
\hline Minutes in home production & 259.0 & 273.8 & 271.9 & 172.0 & 237.0 & 265.8 \\
\hline Minutes in leisure & 1049.1 & 1010.7 & 982.2 & 1138.6 & 1048.1 & 1027.4 \\
\hline
\end{tabular}


Table 3: Descriptive Statistics of Model Variables

\section{Independent Variables}

Education

Age

Husband's Earnings (in thousands \$)

Married spouse present

Nonwhite

Hispanic

Urban

South

Number of kids 0 to 2

Number of kids 3 to 5

Number of kids 6 to 9

Number of kids 10 to 12

Number of kids 13 to 17

Presence of other adults in the household

Summer

Predicted wages

Predicted price of child care for children 0 to 5

Predicted price of child care for children 6 to 12
Weekday

$\begin{array}{rrrr}\text { Means } & \text { Std Dev } & \text { Means } & \text { Std Dev } \\ 13.5689 & 2.9673 & 13.5009 & 3.0701 \\ 35.8457 & 9.2742 & 35.9284 & 9.1770 \\ 2.5509 & 2.8854 & 2.5558 & 2.9012 \\ 0.6221 & 0.4850 & 0.6282 & 0.4834 \\ 0.1875 & 0.3905 & 0.1977 & 0.3984 \\ 0.1578 & 0.3647 & 0.1692 & 0.3751 \\ 0.8208 & 0.3837 & 0.8048 & 0.3965 \\ 0.3363 & 0.4726 & 0.3502 & 0.4772 \\ 0.3564 & 0.5690 & 0.3595 & 0.5652 \\ 0.3938 & 0.5948 & 0.3947 & 0.5663 \\ 0.5287 & 0.6468 & 0.5423 & 0.6596 \\ 0.4311 & 0.5756 & 0.4212 & 0.5887 \\ 0.2671 & 0.5360 & 0.2699 & 0.5407 \\ 0.2000 & 0.4001 & 0.2063 & 0.4048 \\ 0.2657 & 0.4419 & 0.2464 & 0.4311 \\ 2.3387 & 0.4193 & 2.3296 & 0.4267 \\ 2.9698 & 2.8413 & 3.0178 & 2.8440 \\ 2.0234 & 1.8831 & 1.9766 & 1.8873\end{array}$


Table 4a: Marginal Effects of Determinants of Minutes Spent in Leisure, Child Care, Home Production, and Employment on Weekdays

$\begin{array}{lcccc} & \text { Leisure } & \text { Child care } & \text { Home Production } & \text { Employment } \\ \text { Constant } & 1126.8380^{* * *} & -49.6952^{* * *} & 191.3162^{* * *} & -142.737^{* * *} \\ \text { Education } & 3.5615 & -1.3499^{* * *} & -1.0196 & -6.4186 \\ \text { Age } & 0.2006 & -1.003^{* *} & 2.4817^{* * *} & -1.2418^{* *} \\ \text { Husband's earnings if married } & 2.8561 & 3.3838^{* *} & 7.7990^{* * *} & -12.5366^{* * *} \\ \text { Married spouse present } & -34.6962^{* *} & -24.8966^{* *} & 27.0028^{* *} & 36.74948^{* *} \\ \text { Nonwhite } & 28.3305^{* *} & -13.1213^{*} & -12.9236 & -12.1312 \\ \text { Hispanic } & -60.3406^{* * *} & 3.8213 & 3.5383 & 47.1855^{* * *} \\ \text { Urban } & 28.2183 & -15.4076^{* *} & -4.2114 & -6.3245 \\ \text { South } & -15.8720 & 15.3447^{* *} & -1.1925 & -2.6125 \\ \text { Num kids aged 0 to 2 } & -31.2335^{*} & 70.2370^{* * *} & 11.0582 & -38.7074^{* * *} \\ \text { Num kids aged } 3 \text { to 5 } & -22.5108 & 28.3464^{* * *} & -11.5492 & -6.0552 \\ \text { Num kids aged } 6 \text { to 9 } & -31.8655^{* * *} & 24.6079^{* * *} & 14.8789^{* *} & 10.2257 \\ \text { Num kids aged 10 to 12 } & -21.5881^{*} & 15.2517^{* * *} & 35.6205^{* * *} & -28.7272^{* *} \\ \text { Num kids aged 13 to 17 } & -2.1481 & -1.3806 & 5.4408 & -5.8453 \\ \text { Presence of other adult in hh } & 28.6174^{*} & -30.5086^{* * *} & 12.0608 & -33.1538^{* *} \\ \text { Summer } & 43.0892^{* * *} & -27.0622^{* * *} & -2.0230 & 1.9105 \\ \text { Predicted Hourly Wage } & -141.8880^{* * *} & 145.7373^{* * *} & -70.5748^{* * *} & 198.7000^{* * *} \\ \text { Predicted Pcc for Child 0 to 5 } & 0.9444 & 7.1358^{* * *} & 6.3475^{* *} & -12.4935^{* * *} \\ \text { Predicted Pcc for Child 6 to 12 } & 4.7168 & -1.7244 & -0.0660 & -8.1674^{*}\end{array}$

Significance: '*'=10\%; ' '**'=5\%; '***'=1\%.

\section{Cross-equation correlations}

Rho: leisure/childcare

Rho: leisure/ working

Rho: child care/ working

Rho: leisure/ home production

Rho: child care/ home production

Rho: working/ home production
$-0.2272 * * *$

$-0.5650 * * *$

$-0.2800 * * *$

$-0.0898 * * *$

$0.0453 *$

$-0.5481 * * *$ 
Table 4b: Marginal Effects of Determinants of Minutes Spent in Leisure, Child Care, Home Production, and Employment on Weekends

$\begin{array}{lrrrr} & \text { Leisure } & \text { Child care } & \text { Home Production } & \text { Employment } \\ \text { Constant } & 1255.484^{* * *} & -82.7842^{* * *} & 89.5599^{* * *} & -69.1377^{* * *} \\ \text { Education } & 19.2635^{* * *} & -8.9494^{* *} & -11.2658^{* *} & -2.9610 \\ \text { Age } & 0.7293 & -0.1613 & 1.0995^{* *} & -0.8513^{* * *} \\ \text { Husband's earnings if married } & 0.1866 & 1.9442^{*} & 2.4821 & -4.3951^{* * *} \\ \text { Married spouse present } & -9.5219 & 1.5065 & 19.4376 & -5.0764 \\ \text { Nonwhite } & 13.2013 & -1.3240 & -1.8582 & -8.1818^{*} \\ \text { Hispanic } & 1.5951 & 2.5993 & 11.3560 & 0.2289 \\ \text { Urban } & 33.0258^{* *} & -4.9695 & -19.3522^{*} & -7.8710 \\ \text { South } & 5.6541 & 0.0626 & 0.0223 & 1.3845 \\ \text { Num kids aged 0 to 2 } & -47.9985^{* * *} & 58.8274^{* * *} & -18.6932 & -7.8810 \\ \text { Num kids aged 3 to 5 } & -4.0174 & 3.3756 & -12.4630 & -6.1251 \\ \text { Num kids aged 6 to 9 } & -16.1478^{*} & 12.9219^{* * *} & 11.7730^{*} & -6.1082^{* *} \\ \text { Num kids aged 10 to 12 } & -19.1951^{*} & -15.9812^{* * *} & 19.2328^{* *} & 3.9711 \\ \text { Num kids aged 13 to 17 } & 2.0416 & -21.0270^{* * *} & -12.0912 & 9.2404^{* *} \\ \text { Presence of other adult in hh } & -13.4803 & -19.8374 * * * & -11.4879 & 21.6870^{* * *} \\ \text { Summer } & 23.9861^{*} & 1.9660 & -8.9959 & -12.3242^{* * *} \\ \text { Predicted Hourly Wage } & -217.2136^{* * *} & 114.2975^{* * *} & 106.7825^{* * *} & 43.1309^{* *} \\ \text { Predicted Pcc for Child 0 to 5 } & -4.6809 & 0.8382 & 3.9213 & 4.2427^{* * *} \\ \text { Predicted Pcc for Child 6 to 12 } & 4.6789 & -5.8413^{* * *} & 0.6182 & 2.0074 \\ \text { Significance: '*'=10\%; '**'=5\%; '***'=1\%. } & & & & \end{array}$

\section{Cross-equation correlations}

Rho: leisure/childcare

Rho: leisure/ working

Rho: child care/ working

Rho: leisure/ home production

Rho: child care/ home production

Rho: working/ home production
$-0.2982 * * *$

$-0.5543 * * *$

$-0.0259$

$-0.5057 * * *$

$-0.1369 * * *$

$-0.1475 * * *$ 


\section{Table 5: Estimated Elasticities of Price of Time on Time Use in Four Activities}

\section{Weekday elasticities}

Predicted Hourly Wage

Predicted Pcc for Child 0 to 5

Predicted Pcc for Child 6 to 12

\section{Weekend elasticities}

Predicted Hourly Wage

Predicted Pcc for Child 0 to 5

Predicted Pcc for Child 6 to 12

Leisure
$-0.1685^{* * *}$
0.0027
0.0103
Leisure
$-0.2120 * * *$
$-0.0114$
0.0084

\author{
Home \\ production \\ $-0.3656^{* * *}$ \\ $0.0792 * *$ \\ $-0.0006$
Employment $0.8181 * * *$
$-0.1239 * * *$
-0.0620 *

Home

production

$0.4211^{* * *}$

0.0385

0.0045
Employment
$0.7358^{* *}$
$0.1802 * * *$
0.0631

Significance: '*'=10\%; '**'=5\%; '***'=1\% of the underlying coefficients. 
Appendix A: ATUS Activity Lexicon for 2003 data

Activity assignments

To note:

I. 6 digits total: 2 for major category, 2 for $2^{\text {nd }}$ tier, 2 for $3^{\text {rd }}$ tier.

01

01

01

II. Abbreviations: $\mathrm{HH}=$ household; $\mathrm{CC}=$ child care

III. Detailed assignment categories:

$1=$ sleeping/personal care

2=leisure, regular

$3=$ leisure, volunteer

$4=$ formal education

$5=$ paid work, regular

6=unpaid work investment

$7=\mathrm{HH}$ production

$8=$ child care

IV: Aggregated assignment categories

$\mathrm{m}=5$

$\mathrm{hp}=7$

$\mathrm{cC}=8$

$\mathrm{L}=1+2+3$

V. Actual code assignments

01: personal care: 1

02: $\mathrm{HH}$ activities: 7

03: Caring...

$01 \mathrm{CC}=8$

$02 \mathrm{CC}=8$

$03 \mathrm{CC}=8$

04, 05, 99: $\mathrm{HH}=7$

04: Caring: all $\mathrm{HH}=7$

05 Working and work-related activities

01: paid work $=5$

02: treat as $\mathrm{OJT}=6$

03: 5

04: Job search and interviewing: 6 
99: 6

06: Education: all in leisure/formal education: 4

07: Consumer purchases: $\mathrm{HH}$ production $=7$

08: Professional and personal care services

$$
\begin{aligned}
& \text { 01: chcare }=8 \\
& 02=\mathrm{HH}=7 \\
& 03=\mathrm{HH}=7 \\
& 04,05: 1 \\
& 06 \text { thru } 99=7
\end{aligned}
$$

09: HH services: all in 7

10: Government...

01: 7

02: 3

03 thru 99: 7

11: Eating, etc: all in 2

12: Socializing, etc: all in 2

13: Sports, etc. all in 2

14: Religious: all in 2

15: Volunteer activities: all in 3

16: Telephone calls:

01 telephone calls:

01, 02: 2

03: 4

04 thru 08: 7

17: Traveling

01: 1

02: 7

03: travel related to...

01: 8

02, 99: 7

04: 3

05: 6

06: 4

07: 7

08: travel related to using...

01: 8

02, 03: 7 
04, 05: 1

06 thru 99: 7

09: 7

10: travel related to using govt...

01, 02, 03, 99: 7

04: 3

11: travel related to eating and drinking: 2

12: 2

13: 2

14: 2

15: 3

16: 7

17: 2

99: 2

50: : exclude all 
Appendix Table B1: Determinants of Minutes Spent in Leisure, Child Care, Home Production, and Employment for Weekdays

\begin{tabular}{|c|c|c|c|c|}
\hline \multirow[b]{3}{*}{ Constant } & \multicolumn{3}{|c|}{ Child care } & \multirow[t]{2}{*}{ Employment } \\
\hline & Leisure & & Home Production & \\
\hline & $\begin{array}{c}1126.8383 * * * \\
(45.970)\end{array}$ & $\begin{array}{l}-57.9474 * * * \\
(19.878)\end{array}$ & $\begin{array}{c}214.0365 * * * \\
(31.661)\end{array}$ & $\begin{array}{c}-212.2827 * * * \\
(60.224)\end{array}$ \\
\hline Education/100 & $\begin{array}{l}356.1466 \\
(495.956)\end{array}$ & $\begin{array}{c}-1574.1117 * * * \\
(300.378)\end{array}$ & $\begin{array}{l}-114.0713 \\
(397.606)\end{array}$ & $\begin{array}{l}-954.5908 \\
(767.890)\end{array}$ \\
\hline Age/100 & $\begin{array}{l}20.0583 \\
(68.072)\end{array}$ & $\begin{array}{c}-116.9543 * * \\
(46.422)\end{array}$ & $\begin{array}{c}277.6420 * * * \\
(50.860)\end{array}$ & $\begin{array}{c}-184.6788 * \\
(104.946)\end{array}$ \\
\hline $\begin{array}{l}\text { Husband's } \\
\text { earnings if married/10,000 }\end{array}$ & $\begin{array}{l}28.5611 \\
(32.402)\end{array}$ & $\begin{array}{c}39.4567 * * \\
(16.888)\end{array}$ & $\begin{array}{c}87.2520 * * * \\
\quad(21.853)\end{array}$ & $\begin{array}{c}-186.4480 * * * \\
(48.631)\end{array}$ \\
\hline Married spouse present & $\begin{array}{c}-34.6962 * * \\
(17.545)\end{array}$ & $\begin{array}{c}-29.0308 * * * \\
(9.640)\end{array}$ & $\begin{array}{c}30.2096 * * \\
(13.496)\end{array}$ & $\begin{array}{c}54.6548 * * \\
(26.003)\end{array}$ \\
\hline Nonwhite & $\begin{array}{c}28.3305 * * \\
(14.407)\end{array}$ & $\begin{array}{c}-15.3002 * \\
(8.011)\end{array}$ & $\begin{array}{l}-14.4584 \\
(12.065)\end{array}$ & $\begin{array}{l}-18.0418 \\
(22.238)\end{array}$ \\
\hline Hispanic & $\begin{array}{c}-60.3406 * * * \\
(17.842)\end{array}$ & $\begin{array}{l}4.4559 \\
(7.769)\end{array}$ & $\begin{array}{c}3.9585 \\
(13.600)\end{array}$ & $\begin{array}{c}70.1755 * * * \\
(26.206)\end{array}$ \\
\hline Urban & $\begin{array}{l}28.2183 \\
(17.597)\end{array}$ & $\begin{array}{c}-17.9661 \text { ** } \\
(7.875)\end{array}$ & $\begin{array}{l}-4.7115 \\
(13.381)\end{array}$ & $\begin{array}{l}-9.4059 \\
(23.794)\end{array}$ \\
\hline South & $\begin{array}{l}-15.8723 \\
(12.715)\end{array}$ & $\begin{array}{c}17.8928 * * \\
(8.162)\end{array}$ & $\begin{array}{l}-1.3341 \\
(9.810)\end{array}$ & $\begin{array}{l}-3.8854 \\
(18.874)\end{array}$ \\
\hline Num kids aged 0 to 2 & $\begin{array}{c}-31.2335 * \\
(16.755)\end{array}$ & $\begin{array}{l}81.9004 * * * \\
(8.200)\end{array}$ & $\begin{array}{l}12.3714 \\
(12.590)\end{array}$ & $\begin{array}{c}-57.5666 * * \\
(22.415)\end{array}$ \\
\hline Num kids aged 3 to 5 & $\begin{array}{l}-22.5108 \\
(15.991)\end{array}$ & $\begin{array}{l}33.0535 * * * \\
\quad(8.311)\end{array}$ & $\begin{array}{l}-12.9207 \\
(11.912)\end{array}$ & $\begin{array}{l}-9.0055 \\
(19.056)\end{array}$ \\
\hline Num kids aged 6 to 9 & $\begin{array}{l}-31.8655 * * * \\
\quad(11.429)\end{array}$ & $\begin{array}{l}28.6942 * * * \\
\quad(6.136)\end{array}$ & $\begin{array}{l}16.6459 * * \\
(7.934)\end{array}$ & $\begin{array}{l}15.2079 \\
(16.500)\end{array}$ \\
\hline Num kids aged 10 to 12 & $\begin{array}{c}-21.5881 * \\
(11.980)\end{array}$ & $\begin{array}{l}17.7844 * * * \\
\quad(6.023)\end{array}$ & $\begin{array}{l}39.8507 * * * \\
\quad(8.254)\end{array}$ & $\begin{array}{c}-42.7239 * * \\
(17.372)\end{array}$ \\
\hline Num kids aged 13 to 17 & $\begin{array}{l}-2.1481 \\
(11.333)\end{array}$ & $\begin{array}{l}-1.6098 \\
(6.518)\end{array}$ & $\begin{array}{l}6.0869 \\
(8.882)\end{array}$ & $\begin{array}{l}-8.6933 \\
(16.768)\end{array}$ \\
\hline Presence of other adult in hh & $\begin{array}{c}28.6174 * * \\
(14.429)\end{array}$ & $\begin{array}{l}-35.5748 * * * \\
\quad(8.743)\end{array}$ & $\begin{array}{l}13.4931 \\
(10.638)\end{array}$ & $\begin{array}{l}-49.3072 * * \\
(20.735)\end{array}$ \\
\hline Summer & $\begin{array}{l}43.0892 * * * \\
\quad(12.861)\end{array}$ & $\begin{array}{l}-31.5561 * * * \\
\quad(7.497)\end{array}$ & $\begin{array}{l}-2.2632 \\
(9.159)\end{array}$ & $\begin{array}{c}2.8413 \\
(17.324)\end{array}$ \\
\hline Predicted Hourly Wage/10 & $\begin{array}{c}-1418.8799 * * * \\
\quad(394.140)\end{array}$ & $\begin{array}{l}1699.3798 * * * \\
\quad(276.825)\end{array}$ & $\begin{array}{c}-789.5610 * * * \\
(303.575)\end{array}$ & $\begin{array}{c}2955.1187 * * * \\
(617.251)\end{array}$ \\
\hline $\begin{array}{l}\text { Predicted Hourly Price of Child } \\
\text { Care for Child } 0 \text { to } 5 / 10\end{array}$ & $\begin{array}{c}9.4436 \\
(46.038)\end{array}$ & $\begin{array}{l}83.2072 * * * \\
(23.778)\end{array}$ & $\begin{array}{l}71.0131 * * \\
(32.402)\end{array}$ & $\begin{array}{c}-185.8066 * * * \\
(60.893)\end{array}$ \\
\hline $\begin{array}{l}\text { Predicted Hourly Price of Child } \\
\text { Care for Child } 6 \text { to } 12 / 10\end{array}$ & $\begin{array}{l}47.1682 \\
(48.242)\end{array}$ & $\begin{array}{l}-20.1073 \\
(29.987)\end{array}$ & $\begin{array}{l}-0.7379 \\
(36.414)\end{array}$ & $\begin{array}{l}-121.4676 * \\
(67.285)\end{array}$ \\
\hline Sigma & $\begin{array}{c}205.0737 * * * \\
(4.083)\end{array}$ & $\begin{array}{c}126.0665 * * * \\
(1.730)\end{array}$ & $\begin{array}{c}158.7833 * * * \\
(3.330)\end{array}$ & $\begin{array}{l}319.2938 * * * \\
\quad(11.002)\end{array}$ \\
\hline $\mathrm{N}$ & 1445 & & & \\
\hline
\end{tabular}

NOTE: Asymptotic standard errors in parentheses; Significance: '*'=10\%; '**'=5\%; ' $* * * '=1 \%$. 


\section{Appendix Table B2: Determinants of Minutes Spent in Leisure, Child Care, Home Production, and Employment for Weekends}

\begin{tabular}{|c|c|c|c|c|}
\hline Constant & $\begin{array}{l}\text { Leisure } \\
1255.4840 * * * \\
\quad(46.051)\end{array}$ & $\begin{array}{l}\text { Child care } \\
\qquad-110.7631 * * * \\
\quad(19.748)\end{array}$ & $\begin{array}{l}\text { Home } \\
\text { Production } \\
95.6870 * * * \\
\quad(36.387)\end{array}$ & $\begin{array}{c}-275.4297 * * * \\
(65.295)\end{array}$ \\
\hline Education/100 & $\begin{array}{c}1926.3525 * * * \\
(551.601)\end{array}$ & $\begin{array}{c}-1197.4099 * * * \\
(274.139)\end{array}$ & $\begin{array}{c}-1203.6585 \\
(399.874)\end{array}$ & $\begin{array}{l}-1179.61 \\
(814.259)\end{array}$ \\
\hline Age/100 & $\begin{array}{l}72.9251 \\
(75.432)\end{array}$ & $\begin{array}{l}-21.5805 \\
(37.903)\end{array}$ & $\begin{array}{c}117.4752 * * \\
(54.918)\end{array}$ & $\begin{array}{c}-339.1315 * * * \\
\quad(119.110)\end{array}$ \\
\hline $\begin{array}{l}\text { Husband's } \\
\text { earnings if married/10,000 }\end{array}$ & $\begin{array}{c}1.8656 \\
(30.801)\end{array}$ & $\begin{array}{c}26.0133 * \\
(14.401)\end{array}$ & $\begin{array}{l}26.5191 \\
(23.190)\end{array}$ & $\begin{array}{c}-175.0901 * * * \\
\quad(43.493)\end{array}$ \\
\hline Married spouse present & $\begin{array}{l}-9.5219 \\
(16.843)\end{array}$ & $\begin{array}{l}2.0156 \\
(9.495)\end{array}$ & $\begin{array}{l}20.7674 \\
(13.835)\end{array}$ & $\begin{array}{l}-20.2231 \\
(21.397)\end{array}$ \\
\hline Nonwhite & $\begin{array}{l}13.2013 \\
(14.866)\end{array}$ & $\begin{array}{l}-1.7715 \\
(6.924)\end{array}$ & $\begin{array}{l}-1.9853 \\
(10.797)\end{array}$ & $\begin{array}{c}-32.5943 * \\
(19.266)\end{array}$ \\
\hline Hispanic & $\begin{array}{c}1.5951 \\
(18.070)\end{array}$ & $\begin{array}{l}3.4778 \\
(8.583)\end{array}$ & $\begin{array}{l}12.1329 \\
(14.245)\end{array}$ & $\begin{array}{c}0.9119 \\
(22.998)\end{array}$ \\
\hline Urban & $\begin{array}{c}33.0258 * * \\
(16.577)\end{array}$ & $\begin{array}{l}-6.6491 \\
(9.252)\end{array}$ & $\begin{array}{c}-20.6762 * \\
(12.357)\end{array}$ & $\begin{array}{l}-31.3564 \\
(23.104)\end{array}$ \\
\hline South & $\begin{array}{c}5.6541 \\
(12.256)\end{array}$ & $\begin{array}{l}0.0837 \\
(6.662)\end{array}$ & $\begin{array}{l}0.0238 \\
(9.331)\end{array}$ & $\begin{array}{c}5.5154 \\
(16.614)\end{array}$ \\
\hline Num kids aged 0 to 2 & $\begin{array}{c}-47.9985 * * * \\
(16.294)\end{array}$ & $\begin{array}{l}78.7095 * * * \\
\quad(7.002)\end{array}$ & $\begin{array}{l}-19.9721 \\
(12.450)\end{array}$ & $\begin{array}{l}-31.3961 \\
(21.840)\end{array}$ \\
\hline Num kids aged 3 to 5 & $\begin{array}{l}-4.0174 \\
(16.403)\end{array}$ & $\begin{array}{l}4.5165 \\
(8.411)\end{array}$ & $\begin{array}{l}-13.3156 \\
(12.881)\end{array}$ & $\begin{array}{l}-24.401 \\
(22.564)\end{array}$ \\
\hline Num kids aged 6 to 9 & $\begin{array}{c}-16.1478 * \\
(9.514)\end{array}$ & $\begin{array}{c}17.2892 * * * \\
\quad(4.830)\end{array}$ & $\begin{array}{c}12.5784 * \\
(7.441)\end{array}$ & $\begin{array}{c}-24.3338 * * \\
(11.738)\end{array}$ \\
\hline Num kids aged 10 to 12 & $\begin{array}{c}-19.1951 * \\
(10.190)\end{array}$ & $\begin{array}{c}-21.3824 * * * \\
(5.856)\end{array}$ & $\begin{array}{c}20.5486 * * \\
(8.154)\end{array}$ & $\begin{array}{l}15.8201 \\
(13.819)\end{array}$ \\
\hline Num kids aged 13 to 17 & $\begin{array}{c}2.0416 \\
(11.501)\end{array}$ & $\begin{array}{c}-28.1336 * * * \\
\quad(6.785)\end{array}$ & $\begin{array}{l}-12.9184 \\
(7.924)\end{array}$ & $\begin{array}{c}36.8117 * * \\
(14.431)\end{array}$ \\
\hline Presence of other adult in hh & $\begin{array}{l}-13.4803 \\
(14.289)\end{array}$ & $\begin{array}{c}-26.5419 * * * \\
(8.040)\end{array}$ & $\begin{array}{l}-12.2738 \\
(11.482)\end{array}$ & $\begin{array}{c}86.3962 * * * \\
\quad(19.420)\end{array}$ \\
\hline Summer & $\begin{array}{c}23.9861 * \\
(13.053)\end{array}$ & $\begin{array}{l}2.6305 \\
(7.068)\end{array}$ & $\begin{array}{l}-9.6113 \\
(9.747)\end{array}$ & $\begin{array}{c}-49.0970 * * * \\
(18.375)\end{array}$ \\
\hline Predicted Hourly Wage/10 & $\begin{array}{c}-2172.1363 * * * \\
\quad(445.824)\end{array}$ & $\begin{array}{l}1529.2710 * * * \\
\quad(230.901)\end{array}$ & $\begin{array}{l}1140.8793 \\
(328.228)\end{array}$ & $\begin{array}{l}1718.2411 * * \\
\quad(704.634)\end{array}$ \\
\hline $\begin{array}{l}\text { Predicted Hourly Price of Child } \\
\text { Care for Child } 0 \text { to } 5 / 10\end{array}$ & $\begin{array}{l}-46.8088 \\
(45.253)\end{array}$ & $\begin{array}{l}11.2149 \\
(22.707)\end{array}$ & $\begin{array}{l}41.8958 \\
(34.136)\end{array}$ & $\begin{array}{l}169.0200 * * * \\
\quad(61.880)\end{array}$ \\
\hline $\begin{array}{l}\text { Predicted Hourly Price of Child } \\
\text { Care for Child } 6 \text { to } 12 / 10\end{array}$ & $\begin{array}{l}46.7885 \\
(45.227)\end{array}$ & $\begin{array}{l}-78.1553 * * * \\
(21.521)\end{array}$ & $\begin{array}{c}6.6046 \\
(33.968)\end{array}$ & $\begin{array}{l}79.9693 \\
(60.644)\end{array}$ \\
\hline Sigma & $\begin{array}{c}208.1031 * * * \\
(5.005)\end{array}$ & $\begin{array}{c}127.3741 * * * \\
(1.705)\end{array}$ & $\begin{array}{l}167.3200 * * * \\
\quad(2.703)\end{array}$ & $\begin{array}{l}280.4669 * * * \\
\quad(10.116)\end{array}$ \\
\hline $\mathrm{N}$ & 1619 & & & \\
\hline
\end{tabular}


Appendix C1: Determinants of the Natural Log of Hourly Wages for Mothers with Children Aged 0 to 12, Using the 2003 ATUS

\begin{tabular}{|c|c|c|}
\hline Variable Names & Employment & Ln wage \\
\hline Constant & $\begin{array}{c}-3.8160 * * * \\
(0.919)\end{array}$ & $\begin{array}{c}-1.4333^{* * *} \\
(0.391)\end{array}$ \\
\hline Education & $\begin{array}{c}0.1802 * * * \\
(0.055)\end{array}$ & $\begin{array}{c}0.1070 * * * \\
(0.005)\end{array}$ \\
\hline Age & $\begin{array}{l}0.0798 * * * \\
(0.019)\end{array}$ & $\begin{array}{c}0.0823 * * * \\
(0.009)\end{array}$ \\
\hline Education Squared & $\begin{array}{c}-0.0044 * * * \\
(0.002)\end{array}$ & \\
\hline Age Squared & $\begin{array}{c}-0.0011^{* * *} \\
(0.000)\end{array}$ & $\begin{array}{c}-0.0010^{* * *} \\
(0.000)\end{array}$ \\
\hline Education* Age & $\begin{array}{l}0.0002 \\
(0.001)\end{array}$ & \\
\hline $\begin{array}{l}\text { Husband's earnings if } \\
\text { Married }(\$ 1,000)\end{array}$ & $\begin{array}{l}-0.0818^{* * * *} \\
(0.012)\end{array}$ & \\
\hline Married spouse present & $\begin{array}{l}0.0586 \\
(0.074)\end{array}$ & \\
\hline Nonwhite & $\begin{array}{l}0.0134 \\
(0.066)\end{array}$ & $\begin{array}{l}-0.0384 \\
(0.032)\end{array}$ \\
\hline Hispanic & $\begin{array}{l}-0.0475 \\
(0.078)\end{array}$ & $\begin{array}{c}-0.0827^{* *} \\
(0.039)\end{array}$ \\
\hline Urban & $\begin{array}{l}0.0356 \\
(0.065)\end{array}$ & $\begin{array}{c}0.1849 * * * \\
(0.033)\end{array}$ \\
\hline South & $\begin{array}{l}-0.1012 \\
(0.081)\end{array}$ & $\begin{array}{l}-0.0178 \\
(0.032)\end{array}$ \\
\hline Num kids aged 0 to 2 & $\begin{array}{c}-0.3752 * * * \\
(0.048)\end{array}$ & \\
\hline Num kids aged 3 to 5 & $\begin{array}{c}-0.2562 * * * \\
(0.043)\end{array}$ & \\
\hline Num kids aged 6 to 9 & $\begin{array}{c}-0.1011^{* * * *} \\
(0.039)\end{array}$ & \\
\hline Num kids aged 10 to 12 & $\begin{array}{l}-0.0241 \\
(0.046)\end{array}$ & \\
\hline Num kids aged 13 to 17 & $\begin{array}{l}-0.0735 \\
(0.047)\end{array}$ & \\
\hline $\begin{array}{l}\text { Presence of other adult } \\
\text { in household }\end{array}$ & $\begin{array}{l}0.0052 \\
(0.066)\end{array}$ & \\
\hline STCCCREDIT & $\begin{array}{l}-0.0031 \\
(0.069)\end{array}$ & \\
\hline STATEMIN & $\begin{array}{l}-0.1182 \\
(0.107)\end{array}$ & $\begin{array}{c}0.0939 * * * \\
(0.033)\end{array}$ \\
\hline TANFAMT & $\begin{array}{l}-0.0842 \\
(0.330)\end{array}$ & \\
\hline MINTRAIN & $\begin{array}{l}0.0546 \\
(0.069)\end{array}$ & \\
\hline INFANTSZ & $\begin{array}{l}-0.0041 \\
(0.079)\end{array}$ & \\
\hline 4YROLDSZ & $\begin{array}{l}-0.0053 \\
(0.072)\end{array}$ & \\
\hline LICCENTERS & $\begin{array}{l}0.0384 \\
(0.122)\end{array}$ & \\
\hline LICHOMES & $\begin{array}{l}-0.0074 \\
(0.029)\end{array}$ & \\
\hline STMEDICAID & $\begin{array}{l}0.0000 \\
(0.000)\end{array}$ & \\
\hline UNEMPLR & $\begin{array}{l}-0.0286 \\
(0.039)\end{array}$ & $\begin{array}{l}-0.0118 \\
(0.017)\end{array}$ \\
\hline STLFPR & $\begin{array}{l}0.0315^{* * * *} \\
(0.009)\end{array}$ & $\begin{array}{c}0.0102^{* *} \\
(0.004)\end{array}$ \\
\hline LAMBDA & & $\begin{array}{c}0.3003 * * * \\
(0.073)\end{array}$ \\
\hline
\end{tabular}

*** Significance $1 \%$, ** significance $5 \%$, * significance $10 \%$ 
Appendix Table C2: Determinants of Price of Child Care for Mothers of Children 0 to 5 and 6 to 12 Using SIPP 2001, Wave 4

\begin{tabular}{|c|c|c|c|c|c|c|}
\hline \multirow[b]{2}{*}{ Variable Names } & \multicolumn{3}{|c|}{0 to 5 Year Olds } & \multicolumn{3}{|c|}{6 to 12 Year Olds } \\
\hline & Employment & $\begin{array}{l}\text { Pay for } \\
\text { Care }\end{array}$ & $\begin{array}{l}\text { Price of } \\
\text { Child } \\
\text { Care }\end{array}$ & Employment & $\begin{array}{l}\text { Pay for } \\
\text { Care }\end{array}$ & $\begin{array}{l}\text { Price of } \\
\text { Child } \\
\text { Care }\end{array}$ \\
\hline Constant & $\begin{array}{c}-4.4702^{* * *} \\
(0.767)\end{array}$ & $\begin{array}{l}-2.3743 \\
(4.820)\end{array}$ & $\begin{array}{l}2.3727 \\
(5.625)\end{array}$ & $\begin{array}{c}-3.1879 * * * \\
(0.765)\end{array}$ & $\begin{array}{l}1.7891 \\
(1.458)\end{array}$ & $\begin{array}{l}-2.2517 \\
(7.407)\end{array}$ \\
\hline Education & $\begin{array}{l}0.2162 * * * \\
(0.043)\end{array}$ & $\begin{array}{l}-0.1343 \\
(0.234)\end{array}$ & $\begin{array}{l}-0.0654 \\
(0.129)\end{array}$ & $\begin{array}{c}0.0944^{* *} \\
(0.040)\end{array}$ & $\begin{array}{c}-0.2097 * * * \\
(0.060)\end{array}$ & $\begin{array}{l}0.1417 \\
(0.216)\end{array}$ \\
\hline Age & $\begin{array}{l}0.1002^{* * * *} \\
(0.018)\end{array}$ & $\begin{array}{l}0.1001 \\
(0.078)\end{array}$ & $\begin{array}{c}0.0494 * * \\
(0.023)\end{array}$ & $\begin{array}{c}0.0917 * * * \\
(0.018)\end{array}$ & $\begin{array}{r}-0.0192 \\
(0.039)\end{array}$ & $\begin{array}{l}0.0289 \\
(0.039)\end{array}$ \\
\hline Education Squared & $\begin{array}{l}-0.0019 \\
(0.001)\end{array}$ & $\begin{array}{l}0.0015 \\
(0.004)\end{array}$ & & $\begin{array}{l}-0.0002 \\
(0.001)\end{array}$ & $\begin{array}{c}0.0049 * * * \\
(0.002)\end{array}$ & $\begin{array}{l}0.0016^{*} \\
(0.001)\end{array}$ \\
\hline Age Squared & $\begin{array}{c}-0.0010^{* * * *} \\
(0.000)\end{array}$ & $\begin{array}{c}-0.0026^{* * *} \\
(0.001)\end{array}$ & & $\begin{array}{c}-0.0013^{* * *} \\
(0.000)\end{array}$ & $\begin{array}{r}-0.0002 \\
(0.001)\end{array}$ & \\
\hline Education* Age & $\begin{array}{c}-0.0022 * * * \\
(0.001)\end{array}$ & $\begin{array}{l}0.0049 * \\
(0.0030)\end{array}$ & & $\begin{array}{l}-0.0001 \\
(0.001)\end{array}$ & $\begin{array}{l}0.0026 \\
(0.002)\end{array}$ & \\
\hline $\begin{array}{l}\text { Husband's earnings if } \\
\text { Married }(\$ 1,000)\end{array}$ & $\begin{array}{c}-0.0560 * * * \\
(0.006)\end{array}$ & $\begin{array}{l}0.0172 \\
(0.052)\end{array}$ & $\begin{array}{c}0.2117^{* *} \\
(0.090)\end{array}$ & $\begin{array}{c}-0.0327 * * * \\
(0.006)\end{array}$ & $\begin{array}{c}0.0236 * * * \\
(0.009)\end{array}$ & \\
\hline Married spouse present & $\begin{array}{l}-0.0426 \\
(0.053)\end{array}$ & $\begin{array}{c}-0.3335 * * * \\
(0.075)\end{array}$ & $\begin{array}{l}0.3258 \\
(0.327)\end{array}$ & $\begin{array}{c}-0.0846^{*} \\
(0.049)\end{array}$ & $\begin{array}{c}-0.1660^{* *} \\
(0.083)\end{array}$ & $\begin{array}{l}-0.2675 \\
(0.568)\end{array}$ \\
\hline Nonwhite & $\begin{array}{l}-0.0661 \\
(0.052)\end{array}$ & $\begin{array}{l}0.0177 \\
(0.088)\end{array}$ & $\begin{array}{l}0.0358 \\
(0.323)\end{array}$ & $\begin{array}{l}-0.0564 \\
(0.048)\end{array}$ & $\begin{array}{l}-0.0808 \\
(0.070)\end{array}$ & $\begin{array}{l}-0.3909 \\
(0.561)\end{array}$ \\
\hline Hispanic & $\begin{array}{l}-0.0716 \\
(0.060)\end{array}$ & $\begin{array}{l}0.0464 \\
(0.107)\end{array}$ & $\begin{array}{l}0.2605 \\
(0.406)\end{array}$ & $\begin{array}{l}-0.0614 \\
(0.058)\end{array}$ & $\begin{array}{l}-0.0387 \\
(0.080)\end{array}$ & $\begin{array}{l}-0.6688 \\
(0.687)\end{array}$ \\
\hline Urban & $\begin{array}{l}0.0104 \\
(0.052)\end{array}$ & $\begin{array}{l}0.0368 \\
(0.069)\end{array}$ & $\begin{array}{l}0.0222 \\
(0.314)\end{array}$ & $\begin{array}{l}-0.0105 \\
(0.050)\end{array}$ & $\begin{array}{l}0.1146^{*} \\
(0.061)\end{array}$ & $\begin{array}{l}1.0261^{*} \\
(0.541)\end{array}$ \\
\hline South & $\begin{array}{l}0.0165 \\
(0.065)\end{array}$ & $\begin{array}{l}0.0403 \\
(0.087)\end{array}$ & $\begin{array}{c}-0.6643 * * \\
(0.301)\end{array}$ & $\begin{array}{l}0.0513 \\
(0.064)\end{array}$ & $\begin{array}{c}-0.1500^{* *} \\
(0.073)\end{array}$ & $\begin{array}{l}0.2966 \\
(0.474)\end{array}$ \\
\hline Youngest Kid 0 to 2 & $\begin{array}{l}-0.1203 \\
(0.094)\end{array}$ & $\begin{array}{l}-0.2107 \\
(0.164)\end{array}$ & $\begin{array}{l}0.2342 \\
(0.763)\end{array}$ & $\begin{array}{l}-0.0439 \\
(0.066)\end{array}$ & $\begin{array}{c}0.4257^{* * *} \\
(0.121)\end{array}$ & $\begin{array}{l}0.8479 \\
(1.048)\end{array}$ \\
\hline Num kids aged 0 to 2 & $\begin{array}{c}-0.3047 * * * \\
(0.070)\end{array}$ & $\begin{array}{l}-0.1676 \\
(0.273)\end{array}$ & $\begin{array}{l}0.3605 \\
(0.799)\end{array}$ & $\begin{array}{c}-0.3945^{* * * *} \\
(0.040)\end{array}$ & $\begin{array}{l}0.0655 \\
(0.136)\end{array}$ & $\begin{array}{l}-0.4534 \\
(1.088)\end{array}$ \\
\hline Num kids aged 3 to 5 & $\begin{array}{c}-0.2041 * * * \\
(0.040)\end{array}$ & $\begin{array}{l}-0.0834 \\
(0.170)\end{array}$ & $\begin{array}{l}0.5218 \\
(0.386)\end{array}$ & $\begin{array}{c}-0.2569 * * * \\
(0.038)\end{array}$ & $\begin{array}{l}0.0182 \\
(0.093)\end{array}$ & $\begin{array}{l}-0.5693 \\
(0.698)\end{array}$ \\
\hline Num kids aged 6 to 9 & $\begin{array}{c}-0.0870 * * * \\
(0.032)\end{array}$ & $\begin{array}{c}-0.1718^{* * *} \\
(0.067)\end{array}$ & $\begin{array}{l}-0.1524 \\
(0.237)\end{array}$ & $\begin{array}{c}-0.1086^{* * * *} \\
(0.041)\end{array}$ & $\begin{array}{l}-0.1310 \\
(0.090)\end{array}$ & $\begin{array}{l}-0.6199 \\
(0.638)\end{array}$ \\
\hline Num kids aged 10 to 12 & $\begin{array}{l}-0.0159 \\
(0.044)\end{array}$ & $\begin{array}{c}-0.2060 * * * \\
(0.066)\end{array}$ & $\begin{array}{l}-0.0074 \\
(0.333)\end{array}$ & $\begin{array}{l}-0.0140 \\
(0.036)\end{array}$ & $\begin{array}{c}-0.1345^{* *} \\
(0.061)\end{array}$ & $\begin{array}{c}-0.7886^{*} \\
(0.449)\end{array}$ \\
\hline Num kids aged 13 to 17 & $\begin{array}{l}0.0094 \\
(0.040)\end{array}$ & $\begin{array}{l}-0.0991 \\
(0.061)\end{array}$ & $\begin{array}{c}-0.1439 \\
(0.316)\end{array}$ & $\begin{array}{l}0.0212 \\
(0.029)\end{array}$ & $\begin{array}{c}-0.2097 * * * \\
(0.059)\end{array}$ & $\begin{array}{c}-0.9157 * \\
(0.486)\end{array}$ \\
\hline $\begin{array}{l}\text { Presence of other adult } \\
\text { in household }\end{array}$ & $\begin{array}{l}0.0713 \\
(0.055)\end{array}$ & $\begin{array}{c}-0.5073^{* * *} \\
(0.133)\end{array}$ & & $\begin{array}{l}0.0423 \\
(0.050)\end{array}$ & $\begin{array}{c}-0.2112 * * * \\
(0.070)\end{array}$ & \\
\hline STCCCREDIT & $\begin{array}{c}-0.1083^{*} \\
(0.061)\end{array}$ & $\begin{array}{l}0.1674 \\
(0.130)\end{array}$ & $\begin{array}{l}0.2307 \\
(0.333)\end{array}$ & $\begin{array}{c}-0.1154^{* *} \\
(0.058)\end{array}$ & $\begin{array}{c}0.1237 * * \\
(0.063)\end{array}$ & $\begin{array}{l}0.3760 \\
(0.491)\end{array}$ \\
\hline STATEMIN & $\begin{array}{l}0.0737 \\
(0.100)\end{array}$ & $\begin{array}{l}-0.1520 \\
(0.152)\end{array}$ & & $\begin{array}{l}0.0857 \\
(0.097)\end{array}$ & $\begin{array}{l}-0.1258 \\
(0.106)\end{array}$ & \\
\hline TANFAMT & $\begin{array}{l}-0.0002 \\
(0.000)\end{array}$ & $\begin{array}{c}-0.0002^{*} \\
(0.000)\end{array}$ & & $\begin{array}{l}0.0002 \\
(0.000)\end{array}$ & $\begin{array}{c}-0.0006^{*} \\
(0.000)\end{array}$ & \\
\hline
\end{tabular}


Appendix Table C2 continued: Determinants of Price of Child Care for Mothers of Children 0 to 5 and 6 to 12 Using SIPP 2001, Wave 4

\begin{tabular}{|c|c|c|c|c|c|c|}
\hline \multirow[b]{2}{*}{ Variable Names } & \multicolumn{3}{|c|}{0 to 5 Year Olds } & \multicolumn{3}{|c|}{6 to 12 Year Olds } \\
\hline & Employment & $\begin{array}{l}\text { Pay for } \\
\text { Care }\end{array}$ & $\begin{array}{l}\text { Price of } \\
\text { Child } \\
\text { Care }\end{array}$ & Employment & $\begin{array}{l}\text { Pay for } \\
\text { Care }\end{array}$ & $\begin{array}{l}\text { Price of } \\
\text { Child } \\
\text { Care }\end{array}$ \\
\hline MINTRAIN & $\begin{array}{l}0.0472 \\
(0.061)\end{array}$ & $\begin{array}{c}-0.0484 \\
(0.091)\end{array}$ & $\begin{array}{c}-0.5974 * \\
(0.316)\end{array}$ & $\begin{array}{l}0.0314 \\
(0.058)\end{array}$ & $\begin{array}{c}0.1435 * \\
(0.077)\end{array}$ & $\begin{array}{c}0.3663 \\
(0.500)\end{array}$ \\
\hline INFANTSZ & $\begin{array}{l}-0.0160 \\
(0.067)\end{array}$ & $\begin{array}{l}0.1819 * \\
(0.097)\end{array}$ & $\begin{array}{c}0.4860 \\
(0.349)\end{array}$ & $\begin{array}{l}-0.0756 \\
(0.065)\end{array}$ & $\begin{array}{c}0.1426^{* *} \\
(0.072)\end{array}$ & $\begin{array}{l}0.7802 \\
(0.536)\end{array}$ \\
\hline 4YROLDSZ & $\begin{array}{l}-0.0630 \\
(0.060)\end{array}$ & $\begin{array}{l}-0.0899 \\
(0.091)\end{array}$ & $\begin{array}{l}-0.1239 \\
(0.337)\end{array}$ & $\begin{array}{c}-0.1085^{*} \\
(0.059)\end{array}$ & $\begin{array}{c}0.0568 \\
(0.069)\end{array}$ & $\begin{array}{l}0.5680 \\
(0.522)\end{array}$ \\
\hline LICCENTERS & $\begin{array}{l}0.1598 \\
(0.124)\end{array}$ & $\begin{array}{l}0.0991 \\
(0.198)\end{array}$ & $\begin{array}{c}-1.3460^{*} \\
(0.757)\end{array}$ & $\begin{array}{l}0.0794 \\
(0.118)\end{array}$ & $\begin{array}{l}0.1327 \\
(0.144)\end{array}$ & $\begin{array}{c}2.9785 * * * \\
(1.147)\end{array}$ \\
\hline LICHOMES & $\begin{array}{c}0.0567 * * \\
(0.028)\end{array}$ & $\begin{array}{l}-0.0643 \\
(0.062)\end{array}$ & $\begin{array}{c}-0.2380 \\
(0.176)\end{array}$ & $\begin{array}{c}0.0481^{*} \\
(0.029)\end{array}$ & $\begin{array}{r}-0.0055 \\
(0.033)\end{array}$ & $\begin{array}{l}0.0970 \\
(0.268)\end{array}$ \\
\hline STMEDICAID & $\begin{array}{c}-0.0000 \\
(0.000)\end{array}$ & $\begin{array}{l}-0.0000 \\
(0.000)\end{array}$ & & $\begin{array}{l}-0.0000 \\
(0.000)\end{array}$ & $\begin{array}{l}-0.0000 \\
(0.000)\end{array}$ & \\
\hline UNEMPLR & $\begin{array}{l}0.0204 \\
(0.037)\end{array}$ & $\begin{array}{c}0.0973 * * \\
(0.049)\end{array}$ & $\begin{array}{l}0.1255 \\
(0.167)\end{array}$ & $\begin{array}{r}-0.0031 \\
(0.034)\end{array}$ & $\begin{array}{l}0.0277 \\
(0.039)\end{array}$ & $\begin{array}{l}-0.1708 \\
(0.252)\end{array}$ \\
\hline STLFPR & $\begin{array}{c}0.0258 * * * \\
(0.008)\end{array}$ & $\begin{array}{c}0.0178 \\
(0.021)\end{array}$ & $\begin{array}{l}0.0203 \\
(0.053)\end{array}$ & $\begin{array}{c}0.0224 * * * \\
(0.008)\end{array}$ & $\begin{array}{c}-0.0095 \\
(0.010)\end{array}$ & $\begin{array}{l}0.0031 \\
(0.079)\end{array}$ \\
\hline Lambda-A & & & $\begin{array}{l}-0.0090 \\
(0.799)\end{array}$ & & & $\begin{array}{l}0.8585 \\
(2.003)\end{array}$ \\
\hline Lambda-B & & & $\begin{array}{c}-4.6253^{*} \\
(2.423)\end{array}$ & & & $\begin{array}{l}-0.1837 \\
(2.690)\end{array}$ \\
\hline
\end{tabular}

*** Significance 1\%, ** significance 5\%, * significance 10\% 